\title{
Targeting the PI3K/Akt/mTOR Pathway in Hepatocellular Carcinoma
}

\author{
Eun Jin Sun ${ }^{1,2}$, Miriam Wankell ${ }^{1}$, Pranavan Palamuthusingam ${ }^{3,4}$, Craig McFarlane ${ }^{1}$ (D) and Lionel Hebbard ${ }^{1,5, *}$ \\ 1 Centre for Molecular Therapeutics, Department of Molecular and Cell Biology, \\ Australian Institute of Tropical Medicine and Health, College of Public Health, \\ Medical and Veterinary Sciences, James Cook University, Townsville, QLD 4811, Australia; \\ eunjin.sun@my.jcu.edu.au (E.J.S.); miriam.wankell@jcu.edu.au (M.W.); craig.mcfarlane@jcu.edu.au (C.M.) \\ 2 College of Medicine and Dentistry, James Cook University, Townsville, QLD 4811, Australia \\ 3 Institute of Surgery, The Townsville University Hospital, Townsville, QLD 4811, Australia; \\ Pranavan.Palamuthusingam@health.qld.gov.au \\ 4 Mater Hospital, Townsville, QLD 4811, Australia \\ 5 Storr Liver Centre, Westmead Institute for Medical Research, Westmead Hospital and University of Sydney, \\ Sydney, NSW 2145, Australia \\ * Correspondence: lionel.hebbard@jcu.edu.au
}

Citation: Sun, E.J.; Wankell, M.;

Palamuthusingam, P.; McFarlane, C.;

Hebbard, L. Targeting the

PI3K/Akt/mTOR Pathway in

Hepatocellular Carcinoma.

Biomedicines 2021, 9, 1639. https://

doi.org/10.3390/biomedicines9111639

Academic Editor: François

R. Jornayvaz

Received: 19 October 2021

Accepted: 5 November 2021

Published: 8 November 2021

Publisher's Note: MDPI stays neutral with regard to jurisdictional claims in published maps and institutional affiliations.

Copyright: (c) 2021 by the authors. Licensee MDPI, Basel, Switzerland. This article is an open access article distributed under the terms and conditions of the Creative Commons Attribution (CC BY) license (https:// creativecommons.org/licenses/by/ $4.0 /)$.

\begin{abstract}
Despite advances in the treatment of cancers through surgical procedures and new pharmaceuticals, the treatment of hepatocellular carcinoma (HCC) remains challenging as reflected by low survival rates. The PI3K/Akt/mTOR pathway is an important signaling mechanism that regulates the cell cycle, proliferation, apoptosis, and metabolism. Importantly, deregulation of the $\mathrm{PI} 3 \mathrm{~K} / \mathrm{Akt} / \mathrm{mTOR}$ pathway leading to activation is common in HCC and is hence the subject of intense investigation and the focus of current therapeutics. In this review article, we consider the role of this pathway in the pathogenesis of HCC, focusing on its downstream effectors such as glycogen synthase kinase-3 (GSK-3), cAMP-response element-binding protein (CREB), forkhead box O protein (FOXO), murine double minute 2 (MDM2), p53, and nuclear factor- $\mathrm{kB}(\mathrm{NF}-\mathrm{\kappa B})$, and the cellular processes of lipogenesis and autophagy. In addition, we provide an update on the current ongoing clinical development of agents targeting this pathway for HCC treatments.
\end{abstract}

Keywords: hepatocellular carcinoma; HCC; Akt; mTOR; PI3K; clinical trials

\section{Introduction}

Cancer of the liver is represented by cholangiocarcinoma and hepatocellular carcinoma (HCC). HCC constitutes approximately $80-90 \%$ of all primary liver cancers and has a high mortality rate while many are detected in later stages of development and therapeutic options are limited [1]. Worldwide, HCC is now the sixth most common cancer and the fourth leading cause of cancer-related death [2-4]. The major known causes of HCC are alcohol abuse, diabetes, obesity, hepatitis B virus (HBV) and hepatitis $\mathrm{C}$ virus (HCV) infections, aflatoxin B1, and non-alcoholic fatty liver disease (NAFLD) and its progressed form non-alcoholic steatohepatitis (NASH), which was recently renamed metabolic associated fatty liver disease (MAFLD) [5-7]. Together, these promote hepatic inflammation that can progress to fibrosis and cirrhosis, and in turn hepatocyte apoptosis and oxidative stress, leading to altered protein expression, DNA damage, and carcinogenesis. In this regard, formative studies noted mutations and dysregulated expression of the phosphatidylinositol 3-kinase (PI3K)/the serine-threonine protein kinase (Akt)/mammalian target of the rapamycin (mTOR) signaling pathway in HCC. This encouraged the application of small molecule inhibitors of the PI3K/Akt/mTOR pathway in pre-clinical models and subsequent treatment of patients [8-13]. Considering HCC incidence is rapidly increasing worldwide and therapeutic choices are limited, here we consider the role of the $\mathrm{PI} 3 \mathrm{~K} / \mathrm{Akt} / \mathrm{mTOR}$ pathway in HCC, while it is a focus of current clinical practice and subject of intense investigation for future therapeutic development. 


\section{HCC Drivers and Outlook}

Since 1990, there has been a $114 \%$ increase in world-wide liver cancer incidence with significant rises in countries with high socio-demographic indexes, particularly in the USA, Australia, the UK, and the Netherlands $[14,15]$. This has occurred despite the introduction of HBV vaccines in the 1990s and HCV anti-viral therapies in the last decade. These initiatives decreased the rates of HBV- and HCV-driven HCC in developed countries, and these HCC forms are becoming a disease of underdeveloped countries [2-4]. In contrast, with increasing rates of alcohol abuse and NAFLD/MAFLD, the expectation is that HCC incidence will increase in developed countries [16-18]. NAFLD/MAFLD represents conditions ranging in severity from simple steatosis, non-alcoholic steatohepatitis (NASH), to advanced fibrosis and cirrhosis [16]. Recent analyses show the overall global prevalence of NAFLD/MAFLD diagnosis to be in the vicinity of $25 \%$, and it commonly associates with comorbidities such as obesity, diabetes mellitus, and the metabolic syndrome [16,17]. In the US, NAFLD and NASH cases are estimated to increase $21 \%$ and $63 \%$, respectively, by 2030 and this is expected to coincide with increased HCC incidence [19].

\section{Current Treatments of HCC}

Treatment options for early to intermediate stages of HCC remain relatively unchanged, including surgical resection, percutaneous ethanol injection (PEI), radiofrequency ablation (RFA), trans-arterial chemoembolization (TACE), and liver transplantation. However, these procedures are only suitable for a small number of patients, mostly those without cirrhosis, and often have post-operative complications [20]. The introduction of Sorafenib, a multi-kinase inhibitor in 2007, has significantly altered the treatment for intermediate and advanced stage HCC [13]. In advancing intermediate HCCs, the combination of TACE and pharmaceutical agents are frequently used, as this is more effective than monotherapy [21]. Importantly, with the approval of additional drugs, the current algorithm of treatment for advanced HCC includes sorafenib and lenvatinib as first-line and regorafenib, cabozantinib, ramucirumab, nivolumab, and pembrolizumab as second-line add-on pharmaceuticals [22]. Sorafenib, regorafenib, lenvatinib, and cabozantinib are multitargeted tyrosine kinase inhibitors (TKI) that target tumor cell proliferation and angiogenesis pathways. Sorafenib and regorafenib share a common targeting profile as regorafenib is a derivative of sorafenib. Sorafenib targets tyrosine kinase signaling including rapidly accelerated fibrosarcoma (RAF), vascular endothelial growth factor (VEGF) receptors 1-3, and platelet-derived growth factor (PDGF) receptor $\beta$, and regorafenib additionally blocks v-raf murine sarcoma viral oncogene homolog B1 (B-RAF), proto-oncogene c-KIT (KIT), ret proto-oncogene (RET), angiotensin 1 receptor (TIE2), PDGFR $\alpha$, and fibroblast growth receptors (FGFRs) 1 and $2[23,24]$. Lenvatinib is a tyrosine kinase inhibitor that inhibits angiogenesis by targeting VEGFR1-3, fibroblast growth factor receptor (FGFR) 1-4, PDGFR, and tumor cell expressed RET and KIT. Cabozantinib similarly targets the aforementioned proteins, and as well MET (hepatocyte growth factor receptor), neurotrophic receptor kinase 2 (NTRK2), Fms Related Receptor Tyrosine Kinase 3 (FLT3), and AXL receptor tyrosine kinase (AXL). Ramucirumab is a direct binding VEGFR2 antagonist and blocks the binding of VEGF ligands -A, $-\mathrm{C}$, and -D. Nivolumab and pembrolizumab are immune check-point inhibitors and will be discussed in later sections.

Despite sorafenib's usage as a first-line treatment option for advanced HCC, fewer than one-third of patients benefit from treatment and have just three months prolonged median survival time $[13,25]$. Moreover, the use of chemotherapeutic agents can lead to drug resistance within six months of initiation and complications such as drug inefficacy leading to increased dosage and toxicity [25]. This is of concern as the current available first-line drugs are TKIs that target the PI3K/Akt/mTOR pathway. Hence, in this review we will consider the role of the PI3K/Akt/mTOR pathway in HCC, the efficacy of current TKI drugs, and their application in new therapeutic approaches. 


\section{The PI3K/Akt/mTOR Pathway}

The PI3K/Akt/mTOR pathway is a major intracellular signal transduction pathway involved in regulating the cell cycle, cell proliferation, apoptosis, metabolism, and angiogenesis through communicating with its related upstream and downstream molecules and is activated in many cancer types through the action of dysregulated receptor tyrosine kinases (RTK) [26,27]. RTK monomers are high-affinity cell surface receptors for growth factors, cytokines, and hormones that, on ligand binding, become activated and dimerize, causing each monomer to autophosphorylate, leading to downstream activation of the $\mathrm{PI}$ KK/Akt/mTOR pathway [28-30]. Activated RTKs recruit PI3K that phosphorylates phosphatidylinositol on the internal plasma membrane. PI3K is classified into three classes (I, II, and III) according to their structure and substrate specificity, and class IA PI3Ks is the main enzyme that associates with oncogenesis. PI3K can be directly activated by regulatory subunits binding to RTKs and GTP-binding rat sarcoma virus (RAS), or indirectly activated by adaptor molecules such as the insulin receptor substrates (IRS).

Active PI3K phosphorylates phosphatidylinositol-4,5-bisphosphate (PIP2) to phosphatidylinositol-3,4,5-triphosphate (PIP3) [31,32]. PIP3 can interact and recruit 3phosphoinositide dependent protein kinase 1 (PDK1) and Akt to the plasma membrane, and PDK1 phosphorylates Thr308 of the activation loop to partially activate Akt $[33,34]$. $\mathrm{Akt}$, also known as protein kinase B (PKB), is a serine/threonine-specific protein kinase that has an integral role in various cellular mechanisms [35]. Akt consists as three isoforms: Akt1, Akt2, and Akt3, and they are expressed in different tissues within the human body. Akt1 is widely expressed, Akt2 is mainly expressed in insulin-sensitive tissues, and Akt 3 is expressed in the brain and testis. The major difference among these three subtypes are the functional domains that regulate various downstream protein-protein and protein-lipid interactions. Phosphorylation of both Thr308 and Ser473 located in the regulatory region of Akt, respectively by PDK1 and PDK2, are required to complete Akt activation [35]. Akt is also regulated by the tumor suppressor Phosphate and Tensin Homolog (PTEN), a phosphatase that dephosphorylates PIP3 to produce PIP2. Complete Akt activation stimulates targets downstream proteins, including mammalian target of rapamycin (mTOR), glycogen synthase kinase-3 (GSK-3), cAMP-response element binding-protein (CREB), forkhead box O protein (FOXO), p53 and nuclear factor- $\mathrm{k} \beta$ (NF-kB), and cellular processes including lipid metabolism and autophagy.

\section{1. $m T O R$}

mTOR is a serine/threonine protein kinase that is part of the PI3K-associated kinase protein family and mTOR's major cellular role is to regulate cell growth and proliferation through nutritional signals. mTOR is present in two cellular complexes: mTOR complex 1 (mTORC1) and complex 2 (mTORC2). mTORC1 is composed of mTOR, the regulatorassociated protein of mTOR (Raptor), while mTORC2 contains rapamycin-insensitive companion of mTOR (Rictor). Together these proteins act as a framework for assembling the complexes and binding substrates. DEP domain-containing mTOR interacting protein (DEPTOR) and the Mammalian lethal with SEC13 protein 8 (mLST8) associates with both mTORC1 and mTORC2. In addition, mTORC2 contains protein observed with rictor-1 (Protor-1), Protor-2, and mammalian stress-activated protein kinase-interacting protein 1 (mSIN1). Both mTOR complexes also bind with a number of inhibitor proteins that regulate their activity; mTORC1: proline rich Akt substrate 40 (PRAS40) and FKBP38; and mTORC2: exchange factor found in platelet, leukemic, and neuronal tissues (XPLN) that can negatively regulate $\mathrm{mTORC} 2$. mTORC1 regulates cell growth and energy metabolism whereas $\mathrm{mTORC} 2$ is involved in the reconstruction of cytoskeletons and regulation of cell survival.

As a PDK2, mTORC2 phosphorylates Akt on Ser473 to fully activate Akt, that can then in turn activate mTORC1. In addition to phosphorylated Akt, Ras homolog mTORC1 binding (Rheb), a small GTPase, is required for mTORC1 activation. Rheb is normally inhibited by tuberous sclerosis complex subunit 2 (TSC1/2) a GTPase-activating protein (GAP) inhibitor. Akt can inhibit TSC1/2 leading to Rheb and in turn mTOR activation 
in mTORC1. The downstream effectors of mTORC1 include the eukaryotic translation initiation factor $4 \mathrm{E}$ binding protein 1 (4EBP1) and ribosomal proteins S6 kinase 1 and 2 $(\mathrm{S} 6 \mathrm{~K} 1 / 2)$, which are involved in mitochondrial biosynthesis and regulation of mRNA translation. Given these integral roles, the dysregulation of both mTORC1 and mTORC2 has been observed in many human solid tumors. Studies have also shown that mTOR inhibition associates with autophagy activation, and in contrast mTOR hyperactivation can increase lipid production that parallels obesity, diabetes, and fatty liver disease [36-38].

\subsection{Glycogen Synthase Kinase-3 (GSK-3)}

GSK-3 a well-known substrate of Akt, is an ubiquitously expressed serine/threonine protein kinase that exists as two isoforms, GSK-3 $\alpha$ and GSK-3 $\beta$ with 85\% homology [39]. They are constitutively active and inhibit glycogen synthase, the key enzyme in glycogen synthesis. In response to insulin receptor activation, Akt is phosphorylated and in turn phosphorylates and inhibits GSK-3 $\alpha$ on Ser21 and Tyr279 and GSK-3 $\beta$ on Ser9 and Tyr21 [40,41]. GSK-3 controls a range of downstream substrates, including c-Myc, hypoxia inducible transcription factors $1 \alpha(\mathrm{HIF}-1 \alpha)$, sterol regulatory element binding protein $1 \mathrm{c}$ (SREBP1c), and forkhead/winged helix family k1 (Foxk1). Phosphorylation of GSK-3 $\beta$ also leads to the accumulation of $\beta$-catenin within cells and translocation to the nucleus to promote T-cell factor (TCF) transcription targets, such as c-Myc, c-Jun, and cyclin D1 [42]. mTORC1 can also directly modulate GSK-3 activity by restricting GSK3-mediated phosphorylation of Foxk1. This causes the nuclear accumulation of Foxk1 and binding to promoters of several metabolic genes such as those involved in glucose metabolism and HIF-1 $\alpha$ to induce cell growth and tumor development [43]. Reports have shown that GSK-3 $\beta$ upregulation in HCC predicts poor patient prognosis and that GSK-3 $\beta$ inhibition with short-hairpin RNA (shRNA) or specific inhibitors can decrease mTORC1 activity, glycolysis, and HCC growth in vivo [44]. These data illustrate an important role for GSK-3 $\beta$ in HCC.

\section{3. cAMP-Response Element-Binding Protein (CREB)}

Activity of PI3K and Akt also leads to the phosphorylation of the transcription factor cyclic adenosine $3^{\prime}, 5^{\prime}$-monophosphoate (cAMP)-response element binding-protein (CREB) on Ser133 to cause CREB dimerization and activation [45]. CREB binds the CAMP response element (CRE) of gene promoters, is expressed in all nucleated cells, and associates with expression of genes that control proliferation, apoptosis, angiogenesis, metastasis, and metabolism. Additionally, GSK-3 $\beta$ can phosphorylate CREB on Ser129 to enhance activity [46]. Therefore, inhibiting Akt and/or GSK-3 $\beta$ can limit CREB activity and gene activation. CREB expression is also positively regulated by TSC 2 through $\mathrm{mTOR}$, and the dysregulation of mTOR or loss of TSC2 can lead to the overexpression or hyperactivation of CREB, disrupting autophagy regulation. Furthermore, studies show the association of activated CREB with increased HCC invasion and hence poor prognosis [47], and compared to the normal liver, total and phosphorylated CREB proteins are significantly increased in HCC [48]. In addition, under hypoxic conditions, the knockdown of CREB reduced HCC proliferation and limited angiogenesis and made HCC cells susceptible to chemotherapy in vitro and in vivo [49]. In contrast, the over-expression of a positive-dominant CREB mutant supported HCC growth, angiogenesis, and resistance to apoptosis [50]. CREB overexpression also restored the expression of the oncogene Yes-associated protein (YAP) in HCC cells to promote HCC proliferation, and the HBV X protein can enhance this association in HBV-driven HCC [51,52]. Other reports have illustrated that decoy oligonucleotides or p38 MAPK inhibitors promote CREB degradation and the radiosensitivity of HCC cells, suggesting a role for CREB in radiotherapy prognosis in HCC patients [53].

\subsection{Forkhead Box O Protein (FOXO)}

The forkhead box $\mathrm{O}$ protein (FOXO) is a transcription factor and consists of four members: FOXO1, FOXO3, FOXO4, and FOXO6. Akt-mediated phosphorylation of FOXO inhibits their function by promoting their export from the nucleus to the cytoplasm. FOXO1 
is expressed in the liver, pancreas, fat, and muscle tissues, whereas FOXO3 and FOXO4 are expressed in the lymph node, liver, kidney, heart, and skeletal muscles [54]. FOXO6 is mainly expressed in the nervous system, including the brain. FOXOs function by integrating signals such as growth factors, oxidative stress, and other stimulatory signals to induce gene expression of downstream targets involved in cell cycle, metabolism, apoptosis, DNA damage, oxidative stress, and stem cell differentiation. An important regulator of FOXO is insulin signaling, which through Akt leads to FOXO1 and FOXO3 phosphorylation, binding to 14-3-3 proteins, translocation to the cytoplasm, and subsequent dissociation from 14-3-3 for ubiquitination and degradation, to inhibit FOXO-mediated transcription [55,56].

FOXO1 and FOXO3 are the main FOXO proteins that contribute to HCC tumorigenesis and progression [55]. In HCC, hyperactive Akt signaling inhibits FOXO1 transcriptional activity, weakens defense against oxidative stress, and as FOXO1 normally suppresses the expression of epithelial mesenchymal transition (EMT)-inducing transcription factors and transforming growth factor- $\beta$ (TGF- $\beta$ ), leads to subsequent EMT and increased HCC cell migration and invasion [57]. In contrast, reports have established an association between high FOXO3 expression and poor prognosis. In the normal liver, FOXO3 expression is limited, whereas FOXO3 overexpression is observed in more than half of HCCs and correlates with poor disease-free survival and prognosis [58,59]. Furthermore, the doxycycline-regulated over-expression of FOXO3 in the murine liver supported hepatotoxicity-mediated HCC growth, the accumulation and elimination of reactive oxidative species (ROS), and the activation of Akt and mTORC2 signaling [60]. With regards to sorafenib treatment, FOXO3 ablation inhibited sorafenib-induced autophagy and increased cytotoxicity to sorafenib in HCC cells and xenograft tumors, suggesting the development of FOXO3 targeted therapy may be a promising approach to augment sorafenib action [61].

\subsection{Murine Double Minute 2/Human Double Minute2 (MDM2/HDM2)-p53 Axis}

The transcriptional factor p53 acts as a tumor suppressor by modulating apoptosis, cell cycle arrest, and senescence, and is upregulated in response to cellular stresses such as DNA damage, hypoxia, and nutritional starvation [62]. p53 is one of the most often mutated genes in all human cancers as either a gain or loss of function, and contributes to increased proliferation, survival, EMT, and metastasis. p53 mutations are readily observed in HCC with a reported range of 22 to $33 \%$ [63]. However, this varies between geographical regions and presence of hepatitis virus and carcinogen exposure, in particular the combination of $\mathrm{HBV}$ and aflatoxin $\mathrm{B} 1$ exposure where a specific p53 mutation is detected in more than 75\% of HCCs [64].

Normally, p53 protein expression is regulated by the E3 ubiquitin ligase murine double minute 2 (MDM2) by binding to p53 to restrict p53 mediated transcriptional activation, and promote $\mathrm{p} 53$ translocation to the cytoplasm for proteosome-dependent degradation via ubiquitination [62]. In turn, MDM2 is a transcriptional target of p53 and MDM2-p53 homeostasis is maintained through an auto-regulatory negative feedback loop as p53 enhances MDM2 transcription and MDM2 downregulates and degrades p53 in response to excess p53. Additionally, Akt can regulate p53 stability by phosphorylating MDM2 at specific serine residues $(166,183$, or 188$)$ to facilitate MDM2 translocation into the nucleus and reduce p53-dependent gene transactivation, and increase the degradation of p53 [65-67]. Exemplifying the importance of these residues, in murine HCC models, the generation of mice with Ser 183 replaced by alanine in MDM2 reduced HCC load, suggesting that the absence of Ser 183 phosphorylation sensitizes cells to oxidative stressinduced senescence and ultimately HCC progression [68].

In the other direction, p53 can induce genes that restrict PI3K/Akt/mTOR activity. p53 can induce insulin-like growth factor binding protein 3 (IGF-BP3) which binds to insulin growth factor-1 (IGF1) and prevent activation of the IGF receptor and PI3K/Akt signaling. The tumor suppressor PTEN can also be upregulated by p53 to limit PI3K/Akt signaling [69,70]. p53 can also promote the expression of Sestrins $1 / 2$ that bind the major metabolic regulator adenosine monophosphate-activated kinase (AMPK) and TSC1/2 leading to GAP inhibitor activity and reduced mTOR function [71]. Additionally, p53 increases 
the expression of regulated in DNA damage 1 (REDD1) which disrupts the inhibitory association of TSC2 and 14-3-3, causing the release of TSC2 and subsequent mTORC1 inhibition [72,73]. The PI3K/Akt pathway plays an important role in activating glycolysis by stimulating the translocation of glucose transporters (GLUT) to promote glucose uptake and activate glycolytic enzymes. Conversely, stabilized p53 can reduce the activity of the pentose phosphate pathway and promote glutaminolysis and mitochondrial oxidative phosphorylation. Thus, increased, mutated, or absent p53 can have profound effects on $\mathrm{PI} 3 \mathrm{~K} / \mathrm{Ak} / \mathrm{mTOR}$ pathway activity [74]. In this regard, a recent study illustrated that TSC1 deficiency facilitates p53 haploinsufficiency-mediated activation of PTEN/Akt/mTOR axis to promote HCC tumorigenesis and metastasis [75].

\subsection{Nuclear Factor Kappa-Light-Chain-Enhancer of Activated B Cells (NF-kB)}

$\mathrm{PI} 3 \mathrm{~K} / \mathrm{Akt}$ can regulate the NF-KB pathway/family of transcription factors that modulate inflammation, cellular stress, and innate and adaptive immune responses, which, in turn, regulate the survival, proliferation, migration, and invasion of hepatocytes, kupffer cells, and hepatic stellate cells [76]. NF-KB comprises five different family members: RelA (p65), RelB, c-Rel, p105/p50, and p100/p52. The Rel proteins are synthesized as mature proteins, and p50 and p52 are generated by proteosomal degradation of precursor forms p105 and p100, respectively. The proteins share a conserved Rel homology domain, that binds a target DNA sequence, for homo/heterodimerization, and in the absence of any

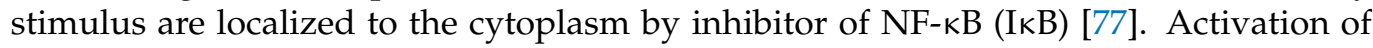
NF- $\mathrm{kB}$ occurs through distinct canonical and non-canonical pathways. In the canonical pathway, the inhibitor IкB is phosphorylated by the IкB kinase (IKK) complex and subjected to ubiquitin-mediated proteasomal degradation. The free NF- $\mathrm{kB}$ dimers (mainly p50/p65 and $\mathrm{p} 50 / \mathrm{c}-\mathrm{Rel})$ then translocate to the nucleus and activate target gene transcription. In the non-canonical pathway, the NF-kB-inducing kinase (NIK) is activated, followed by subsequent post-translational processing of p100 into the p52 subunit, dimerization with RelB, and nuclear localization to cause the induction of gene transcription [78].

The PI3K/Akt/mTOR pathway activates the NF- KB pathway through various mechanisms. The most common is the phosphorylation of IKK and IKB by Akt causing dissociation of I $\kappa B$ from the NF- $\kappa B$ dimers [79]. Akt can also promote IKK activity indirectly through mTOR and the mitogen-activated protein kinase (MAP3K) cancer osaka thyroid (Cot) [80,81]. Given that HCC most often develops in the setting of chronic inflammation, the NF- $\mathrm{kB}$ pathway has been demonstrated to be a major contributor to HCC. Numerous in vitro studies have established that the NF- $\mathrm{KB}$ signaling pathway is aberrantly expressed and activated in human HCC cell lines. Functional studies have shown that the overexpression of $\mathrm{I} \kappa \mathrm{B} \alpha$ in Hep3B cells can lead to an $80 \%$ decrease in cell invasion and the suppression of downstream effectors associated with invasion [82]. In murine models, the chemical carcinogen diethyl nitrosamine (DEN) has often been used to induce HCC, which is similar to human HCC development, and to test the role of the NF- $\mathrm{KB}$ pathway. The hepatocyte deletion of IKK $\beta$, a subunit of IKK, prevented NF- $\mathrm{KB}$ activation and promoted hepatocyte death, but through inflammatory cell action enhanced ROS production, hepatocyte survival, and HCC promotion. In contrast, the absence of IKK $\beta$ in both hepatocytes and Kupffer cells decreased HCC progression [83]. Together, these data show that IKK $\beta$ regulates inflammatory crosstalk between the hepatocytes and immune cells, and that aberrant PI3K/Akt/mTOR signaling could drive these events and HCC progression.

\subsection{Lipid Metabolism}

Increased lipid synthesis is required to generate membranes for new tumor cells. Thus, a prominent metabolic change in cancer is to increase the synthesis and uptake of lipids to support cellular growth, proliferation, and tumorigenesis. The PI3K/Akt/mTOR pathway enhances lipid synthesis through different mechanisms. The most relevant is the transcription factor sterol regulatory element-binding protein-1 (SREBP-1), which is a master regulator of lipid homeostasis as it regulates the expression of genes associated 
with fatty acid, triglyceride, and cholesterol synthesis [84]. SREBP-1 is synthesized in the endoplasmic reticulum (ER) as a precursor protein and to attain nuclear transcriptional activity, the amino domain of SREBP-1 must be released from the ER proteolytically. The processing of SREBP-1 into its mature and active form is influenced by PI3K/Akt/mTORC1 activity, leading to the expression of key lipogenic enzymes, such as fatty acid synthase (FASN), acetyl CoA carboxylase (ACC), and ATP citrate lysate (ACLY) $[85,86]$. Importantly, studies reveal that SREBP-1 expression is significantly higher in HCC tissues, and this correlates with larger tumor size, higher histological grade, and advanced tumornode-metastasis stage [87]. Moreover, the suppression of SREBP-1 inhibits HepG2 cell proliferation, migration, and invasion, and in vivo inhibits HCC growth [88].

An important mechanism to regulate SREBP-1 activity involves the phosphatidate phosphatase Lipin 1, which catalyzes the last step of triglyceride synthesis to dephosphorylate phosphatidic acid to generate diacylglycerol, which on mTORC1 phosphorylation becomes localized to the cytoplasm. In the absence of mTORC1 activity, Lipin 1 is dephosphorylated and enters the nucleus and reduces SREBP-transcriptional activity [89]. mTORC1 can also promote lipogenesis through S6K1-mediated phosphorylation of serine arginine protein kinase (SRPK2), causing nuclear translocation and eventual activation of $\mathrm{U} 1 \mathrm{small}$ nuclear ribonucleoprotein $70 \mathrm{kDa}(\mathrm{U} 1-70 \mathrm{~K})$ to induce splicing of lipogenic pre-mRNAs, such as FASN, acyl-CoA synthetase long chain family member 1 (ACYL), acyl-CoA synthetase short chain member 2 (ACSS2), and 3-hydroxy-3-methylglutaryl-CoA synthase 1 (HMGCS1), that are important in lipid and cholesterol synthesis [90].

As discussed previously, Akt can inhibit GSK-3 by specific phosphorylation and studies reveal that GSK-3 inhibition leads to SREBP-1 stabilization, and in the absence of GSK-3 inhibition, GSK-3 phosphorylates SREBP-1 and it is inhibited [91]. Moreover, Akt activity is responsible for limiting the expression of insulin-induced gene 2 (Insig2), a liver specific gene and inhibitor of SREBP-1 [92]. mTORC2 has also been shown to control liver fatty acid synthesis through Akt and SREBP-1, leading to broad changes in liver fat synthesis, including sphingolipids, glycerophospholipids, and cardiolipins, with the last of those having the ability to bind ATP synthase and improve oxidative respiration. Importantly, inhibition of mTORC2 reduces HCC fat content and tumor load, and suggests that inhibiting mTORC2 could be a strategy to restrict HCC [93].

\subsection{Autophagy}

Autophagy is a cellular catabolic pathway that targets the degradation or removal of unnecessary, dysfunctional, and long-lived proteins and cellular components for lysosomal degradation. This occurs by the unwanted cellular components being packaged into autophagosomes, a double membrane vesicle that fuses with lysosomes, that then leads to the generation of free fatty acids and amino acids that can be recycled to maintain cellular homeostasis [94]. Autophagy is mediated through various autophagy-related proteins (ATGs) that assemble into several complexes to direct the collection, formation of autophagosome, fusion with lysosome, and eventual degradation [95]. The Akt/mTOR pathway is major regulator of autophagy, and under normal physiological conditions when mTORC1 is activated, autophagy is inhibited through the phosphorylation of ATG1 human homologs Unc-51-like autophagy-activating kinase-1 (ULK1) and Unc-51-like autophagyactivating kinase-2 (ULK2) [96,97]. In conditions of hypoxia or starvation, AMPK is activated and phosphorylates Raptor to inhibit mTORC1 leading to the subsequent dephosphorylation of ULK1/2, and the promotion of autophagy $[96,98]$. In addition, GSK-3 $\beta$ can also phosphorylate and activate ULK1 to initiate autophagy while suppressing the mTOR pathway $[99,100]$.

Given that ULK1 activation initiates autophagy and autophagy induction is exhibited by many tumors, elevated ULK1 expression is a feature of human HCC and is associated with tumor size and reduced survival time [101]. Functionally, the silencing and deletion of ULK1 in HepG2 and primary human cells suppressed tumor cell proliferation and increased the therapeutic effects of sorafenib in vitro and in vivo. Moreover, the generation of a specific ULK1 inhibitor XST-14 and used in combination with Sorafenib significantly 
reduces HepG2 tumor growth [102]. Taken together, these data suggest that targeting ULK1 could be a therapeutic approach for treating HCC.

Notwithstanding the aforementioned signaling mediated by the PI3K/Akt/MTOR pathway, it must be mentioned that this pathway is not a stand-alone entity and has cross talk with and can be regulated by the Ras/mitogen-activation protein kinase (MEK)/extracellular signal-regulated kinase (ERK) pathway. The two pathways interact at various signaling points; for example, Akt and mTOR (see review [103]) can be activated by alike growth factors and their concurrent dysregulation is a feature of some HCCs [104]. For further information, we refer readers to recent reviews on the role of Ras/MEK/ERK pathway in HCC $[105,106]$. The major components of the PI3K/Akt/MTOR pathway as discussed in the text are presented in Figure 1.

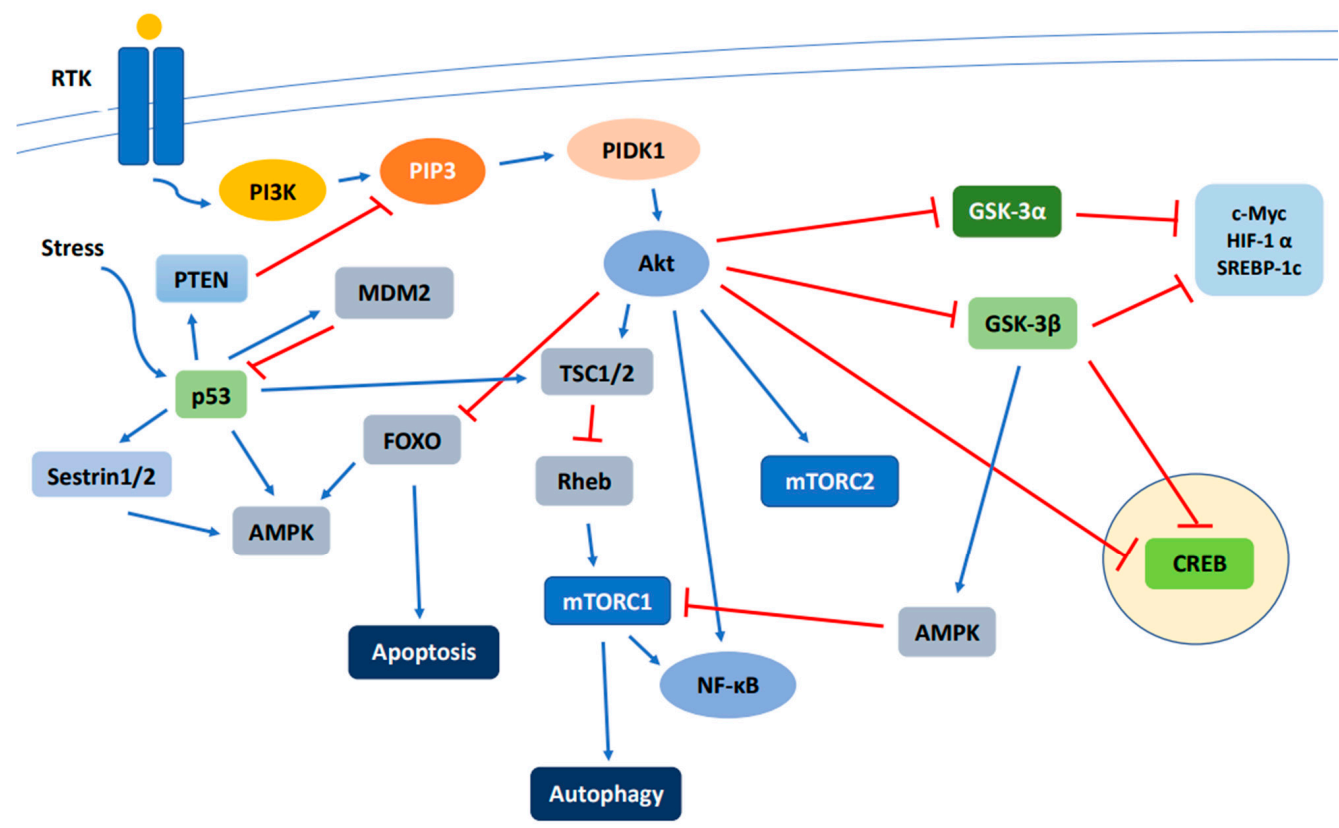

Figure 1. Schematic overview of the major components of the PI3K/Akt/mTOR signaling pathway. Activation of RTK by a ligand in turn activates PI3K, PDK1, and Akt, which regulates downstream effectors including FOXO, mTORC1, mTORC2, CREB, GSK-3 $\alpha$, and GSK-3 $\beta$. Abbreviations: RTK—receptor tyrosine kinase; PI3K-phosphatidylinositol 3-kinase; PIP3 - phosphatidylinositol-3,4,5-triphosphate; PDK1-3-phosphoinositide dependent protein kinase 1; Akt-Akt, protein kinase B; TSC1/2-tuberous sclerosis complex subunit 1/2; Rheb-Ras homolog mTORC1 binding; mTOR-mammalian target of rapamycin; GSK-3 — glycogen synthase kinase-3; c-Myc — cellular Myc; HIF-1 $\alpha$ - hypoxia inducible transcription factors $1 \alpha$; SREBP-1c-sterol regulatory element binding protein-1c; CREB-cAMP-response element-binding protein; FOXO—forkhead box O protein; AMPK—adenosine monophosphate-activated protein kinase; MDM2—murine double minute 2; NF- $\mathrm{B}$ — nuclear factor kappa-light-chain-enhancer of activated B cells; PTEN—phosphatase and tensin homolog. Blue line: positive regulation; Red line: negative regulation.

\section{The Utility of PI3K/Akt/mTOR Inhibitors in HCC Treatment}

Given that the PI3K/Akt/mTOR pathway is aberrantly activated in near $50 \%$ of HCC patients, it is a focus of intense investigation for clinical utility with specific small molecule inhibitors and humanized antibodies to restrict HCC growth. In 2008, the Sorafenib HCC Assessment Randomized Protocol (SHARP) trial (NCT00105443, FDA approval (FDAA) 22 November 2013), a phase III randomized placebo-controlled trial, demonstrated that Sorafenib prolonged median survival and radiologic progression by approximately 3 months in advanced HCC patients (HR $0.69 ; 95 \% \mathrm{CI} 0.55-0.87 ; p<0.001$ ) [13]. The results of the SHARP trial led to the approval of sorafenib for HCC treatment by the US Food and Drug Administration (FDA) as the first systemic therapy option for inoperable advanced HCC. In 2009, another randomized placebo-controlled trial known as the Asian-Pacific (AP) trial (NCT00492752) also reported improved overall survival (OS) of 2.3 months (HR $0.68 ; 95 \%$ CI $0.50-0.94 ; p=0.014$ ), supporting the efficacy of sorafenib in advanced 
HCC [107]. The REFLECT trial (NCT01761266, FDAA 16 August 2018), a randomized phase III trial, compared lenvatinib and sorafenib as a first line treatment option in advanced HCC patients. This trial demonstrated that the efficacy and safety of lenvatinib is similar to sorafenib (HR 0.92; 95\% CI 0.76-1.06) and gained US FDA approval in 2018 as the second first-line systemic treatment option for advanced HCC [108]. Taken together, these three large, randomized trials established the use of sorafenib and lenvatinib to treat advanced HCC and led to the development of numerous clinical guidelines for their use as first line treatment options.

\subsection{Second-Line Treatment Options}

For second-line treatment options, regorafenib is for HCC patients who progressed on sorafenib treatment. A randomized phase III trial (RESORCE; NCT01774344, FDAA 27 April 2017) demonstrated increased median OS of 10.6 months versus 7.8 months for the placebo group (HR 0.63; 95\% CI 0.50-0.79; $p<0.0001$ ) [109]. Together, this showed that regorafenib provided clinical benefit to sorafenib-resistant patients. A follow-up analysis of the RESORCE clinical trial illustrated a prolongation in time from the beginning of sorafenib treatment to death of 26 months for regorafenib versus 19.2 months for placebo [110].

Cabozantinib is an oral multikinase inhibitor that is often used as a second line or add-on drug. It targets receptor tyrosine kinases such as c-MET, VEGRF2, tyrosine-protein kinase receptor UFO (AXL), and RET to inhibit angiogenesis and Akt activation. Similar to the RESORCE trial, the CELESTIAL trial (NCT01908426, FDAA 14 January 2019) compared the efficacy of cabozantinib versus placebo, and targeted advanced HCC patients with prior sorafenib treatment. The mean OS with cabozantinib was 10.2 versus 8.0 months for placebo (HR 0.76; 95\% CI 0.63-0.92; $p=0.0005$ ) and the median progression-free survival (PFS) was 5.2 versus 1.9 months (HR $0.44 ; 95 \%$ CI $0.36-0.52 ; p<0.0001$ ) for cabozantinib compared to placebo [111]. These results, despite a rate of high-grade adverse events, established the effectiveness of cabozantinib as a second-line treatment option for advanced HCC.

In the last decade, humanized antibodies for immunotherapy have been developed to block the interaction of programmed death ligand (PD-L1), which is expressed by tumor cells, with programmed cell death protein 1 (PD-1) present on immune cells, such as T-cells. The purpose of immunotherapies is to block the inhibitory signals mediated between PD-L1 and PD-1 and to promote an anti-tumor response. In 2020, the US FDA approved atezolizumab (a PD-L1 inhibitor) in combination with bevacizumab (a humanized antibody that targets VEGF) as a first-line systemic treatment option for advanced HCC patients without prior systemic treatment [112]. This was based on IMBrave150 (NCT03434379, FDDA 29 May 2020), a randomized phase III study that compared the combination of atezolizumab and bevacizumab versus sorafenib monotherapy. The combination of atezolizumab and bevacizumab increased OS by nearly 6 months (HR 0.66; 95\% CI 0.52-0.85; $p=0.0009$ ) and PFS by 2 months (HR 0.59; 95\% CI $0.47-0.76 ; p<0.001$ ) compared to sorafenib monotherapy [113]. These results illustrated a significantly better OS and PFS for advanced HCC patients receiving atezolizumab and bevacizumab versus sorafenib alone. The results of the current significant systemic treatment options are presented in Table 1.

Table 1. Summary of significant clinical trials for current first-line systemic treatment options of advanced HCC.

\begin{tabular}{|c|c|c|c|c|}
\hline Trial & Drugs & Results (Months) & Statistics & Clinical Trial\# \\
\hline \multirow{3}{*}{ SHARP } & \multirow{3}{*}{ Sorafenib vs. placebo } & OS 10.7 vs. 7.9 & \multirow{3}{*}{$\begin{array}{c}\text { HR } 0.69 ; 95 \% \text { CI } \\
0.55-0.87 ; p<0.001\end{array}$} & \multirow{3}{*}{ NCT00105443 } \\
\hline & & SP 4.1 vs. 4.9 & & \\
\hline & & RP 5.5 vs. 2.8 & & \\
\hline \multirow{2}{*}{ Asian-Pacific } & \multirow{2}{*}{ Sorafenib vs. placebo } & OS 6.5 vs. 4.2 & $\begin{array}{c}\text { HR } 0.68 ; 95 \% \text { CI } \\
0.50-0.94 ; p=0.014\end{array}$ & \multirow{2}{*}{ NCT00492752 } \\
\hline & & TTP 2.8 vs. 1.4 & $\begin{array}{c}\text { HR } 0.57 ; 95 \% \text { CI } \\
0.42-0.79 ; p=0.00005\end{array}$ & \\
\hline
\end{tabular}


Table 1. Cont.

\begin{tabular}{|c|c|c|c|c|}
\hline Trial & Drugs & Results (Months) & Statistics & Clinical Trial\# \\
\hline REFLECT & $\begin{array}{l}\text { Lenvatinib vs. } \\
\text { sorafenib }\end{array}$ & OS 13.6 vs. 12.3 & $\begin{array}{c}\text { HR } 0.92 ; 95 \% \text { CI } \\
0.76-1.06\end{array}$ & NCT01761266 \\
\hline RESORCE & $\begin{array}{l}\text { Regorafenib vs. } \\
\text { placebo }\end{array}$ & OS 10.6 vs. 7.8 & $\begin{array}{c}\text { HR } 0.63 ; 95 \% \text { CI } \\
0.50-0.79 ; p<0.0001\end{array}$ & NCT01774344 \\
\hline \multirow{2}{*}{ CELESTIAL } & \multirow{2}{*}{$\begin{array}{c}\text { Cabozantinib vs. } \\
\text { placebo }\end{array}$} & OS 10.2 vs. 8.0 & $\begin{array}{c}\text { HR } 0.76 ; 95 \% \text { CI } \\
0.63-0.92 ; p=0.005\end{array}$ & \multirow{2}{*}{ NCT01908426 } \\
\hline & & PFS 5.2 vs. 1.9 & $\begin{array}{c}\text { HR } 0.44 ; 95 \% \text { CI } \\
0.36-0.52 ; p<0.001\end{array}$ & \\
\hline \multirow{2}{*}{ IMbrave150 } & \multirow{2}{*}{$\begin{array}{l}\text { Atezolizumab + } \\
\text { bevacizumab vs. } \\
\text { sorafenib }\end{array}$} & OS 19.2 vs. 13.4 & $\begin{array}{c}\text { HR } 0.66 ; 95 \% \text { CI } \\
0.52-0.85 ; p=0.0009\end{array}$ & \multirow{2}{*}{ NCT03434379 } \\
\hline & & PFS 6.8 vs. 4.3 & $\begin{array}{c}\text { HR } 0.59 ; 95 \% \text { CI } \\
0.47-0.76 ; p<0.001\end{array}$ & \\
\hline
\end{tabular}

The details of completed clinical trials were obtained from https: / www.clinicaltrials.gov (accessed on 8 September 2021) and corresponding publications. OS-overall survival; SP — time to symptomatic progression; RP — time to radiologic progression; TTP-time to progress; $\mathrm{HR}$ - hazard ratio, $\mathrm{CI}$ - confidence interval.

\subsection{Clinical Trials Focusing on the PI3K/Akt/mTOR Pathway}

Currently, there are more than 35 ongoing clinical trials targeting the PI3K/Akt/mTOR pathway, and some of the recently completed and ongoing ones we now present. The MATCH Screening Trial (NCT02465060, ongoing) is a phase II clinical trial which will examine the effects of combinations of various inhibitors including sapanisertib (mTORC1/2 inhibitor), GSK2636771 (PI3K $\beta$ inhibitor), capivasertib (ATP-competitive pan-Akt inhibitor), and ipatasertib (Akt inhibitor) in HCC and other cancers. This trial is currently recruiting patients and aims to target advanced tumor patients with no existingtreatment or at least one failed line of standard treatment. For PI3K-targeted clinical trials, SF1126, a dual inhibitor of pan-PI3K and the bromodomain-containing protein 4 (BRD4), an important epigenetic reader, is under a phase I clinical trial for patients with advanced HCC in conjunction with nivolumab (PD-1 immune checkpoint inhibitor; NCT03059147, ongoing) [114].

Nivolumab has been approved as a first-line monotherapy treatment of sorafenibexposed advanced HCC patients. This was based on the results from the CheckMate040 (NCT01658878, FDAA 22 September 2017) and CheckMate459 (NCT02576509, not approved 30 April 2021) expansion trial. The CheckMate040 trial was a phase I/II trial that evaluated the safety and efficacy of Nivolumab. The CheckMate459 trial was a randomized multicenter phase III study and compared the efficacy of nivolumab in comparison to sorafenib to treat advanced HCC [115]. In comparison to sorafenib, nivolumab showed a median OS during the dose-escalation phase of 15.0 months (95\% CI 9.6-20.2) and median time to progression of 3.4 months (95\% CI 1.6-6.9) [115]. The CheckmateMate459 results were not promising as median OS was 16.4 months for nivolumab versus 14.7 months for sorafenib (HR 0.85; 95\% CI 0.72-1.02; $p=0.0752$ ) [116]. In July 2021, nivolumab was voluntarily withdrawn from the market as it failed to meet the requirements for demonstrating benefit in advanced HCC patients. This decision now leaves advanced HCC patients with just three first-line systemic therapies: sorafenib, lenvatinib, and the combination of atezolizumab and bevacizumab.

Given that the clinical trial of atezolizumab and bevacizumab combination was successful, the combination of bevacizumab and erlotinib (EGFR inhibitor) has been explored for its efficacy and safety in an open label phase II trial (NCT01180959, completed 19 May 2021). Erlotinib can prevent activation of Akt signaling pathway. The median OS was 8.55 months in both the bevacizumab and erlotinib combination and sorafenib control group (HR 0.67; 95\% CI 0.42-1.07; $p=0.09$ ), suggesting no difference in efficacy for this combination and sorafenib monotherapy [117]. Another Akt inhibitor, MK2206 
has been considered in two similar clinical trials, but one trial is not specifically for HCC (NCT01425879, ongoing) and the other has been terminated early for discouraging results (NCT01239355, completed 1 February 2013).

Unlike Akt and PI3K inhibitors, mTOR inhibitors have been a more popular target of treatment. Rapalogs, the first generation of mTOR inhibitors, are derived from the antibiotic rapamycin and include everolimus (RAD001), temsirolimus (CCI-779), and sirolimus (rapamycin). Rapalogs are effective in inhibiting HCC cell growth and proliferation as they inhibit phosphorylation of mTOR in vitro and in vivo [118]. Studies examined everolimus as a monotherapy and in secondline combinations in multiple clinical trials. When everolimus was given at 5 or $10 \mathrm{mg} /$ day as a monotherapy, the OS was 8.4 months and only $8 \%$ of patients were progression-free at 24 weeks (NCT00516165, completed 1 November 2011). EVOLVE-1 (NCT01035229, completed 1 October 2013), a randomized, double-blind, phase III clinical trial, tested the efficacy of everolimus in sorafenib-failed advanced HCC patients. However, in this study, everolimus was not effective, as OS was 7.6 months with everolimus versus 7.3 months with placebo (HR 1.05; 95\% CI 0.86-1.27; $p=0.68)[119]$.

In a randomized phase II clinical trial that compared the efficacy of sorafenib with or without everolimus (NCT01005199, completed 1 March 2016), the median OS was 10 months for sorafenib and 12 months for sorafenib with everolimus, and PFS at 12 months was $70 \%$ and $68 \%$, respectively [120]. These results suggest everolimus is not effective in vivo, while as a monotherapy or an add-on there was no prolongation in overall survival. Additionally, another clinical trial that considered the combination of everolimus and MM-141, a monoclonal antibody that targets the insulin-like growth factor 1 receptor (IGF-1R) has been completed, but no result has yet been provided. Other combinations such as bevacizumab and everolimus (NCT00775073, completed 1 April 2012) have been completed and anti-vascular activity has been demonstrated [121]. A clinical trial combining everolimus, trametinib (an inhibitor of the mitogen-activation protein kinase: MEK), and lenvatinib (NCT04803318, ongoing) is active and currently recruiting advanced solid tumor patients, including those with advanced HCC.

Temsirolimus and sirolimus are mTORC1 inhibitors and there are multiple clinical trials associated with both due to their limited efficacy as monotherapies in advanced HCC. A phase I trial of sirolimus combined with bevacizumab (NCT00467194, completed 1 May 2011) is complete with evidence of anti-vascular activity and promising clinical activity [121]. A phase I and phase I/II study of temsirolimus in combination with sorafenib is complete, and the median OS was 8.8 months (95\% CI 6.8-14.8) whereas the previous SHARP and Asian-Pacific studies showed 10.7 and 6.5 months, respectively, and this combination has not become an FDA approved treatment option (NCT01008917, completed 27 June 2013; NCT01687673, completed 9 January 2020). Another phase II trial evaluated the combination of temsirolimus and bevacizumab in advanced cancer patients (NCT01010126, completed 13 March 2017) and demonstrated median PFS of 7 months and OS of 14 months, a significant extension of OS, but as the sample size was small $(n=28)$, further studies are required [122]. Furthermore, two active trials are currently recruiting advanced solid tumor patients to evaluate the efficacy and safety of different combinations of mTOR inhibitors, which include nivolumab and nab-rapamycin (ABI-009; a nanoparticle form of human albumin bound rapamycin) (NCT03190174, ongoing); and trametinib combined with everolimus and lenvatnib (NCT04803318, ongoing). Recently, second generation mTOR inhibitors that are under development have begun to be trialed. A phase I/II clinical trial to assess the safety and efficacy of CC-223, a dual mTOR inhibitor, in advanced solid tumor has been completed, but no results are available (NCT01177397, completed 09 December 2016). Furthermore, two clinical trials are actively recruiting patients to evaluate the safety and efficacy of onatasertib (ATG-008), a dual mTOR inhibitor, for both advanced solid tumors and HBV-positive advanced HCC (NCT04518137, ongoing; NCT03591965, ongoing). Table 2 lists ongoing clinical trials with inhibitors targeting the PI3K/Akt/mTOR signaling pathway in HCC. 
Table 2. Ongoing clinical trials with pharmaceuticals associated with PI3K/Akt/mTOR signaling pathway blockade in HCC.

\begin{tabular}{|c|c|c|c|c|c|c|c|c|}
\hline Drugs & NCT \# & Patients & Phase & Combinations & Dosage & Year & Status & Notes \\
\hline $\begin{array}{l}\text { Sapanisertib, GSK2636771, } \\
\text { Capivasertib, Ipatasertib }\end{array}$ & NCT02465060 & 6452 & II & $\begin{array}{c}\text { Sapanisertib, GSK2636771, } \\
\text { Capivasertib, Ipatasertib }\end{array}$ & Dosages not specified & 2015 & Recruiting & $\begin{array}{c}\text { Aimed for } \\
\text { multiple advanced } \\
\text { solid tumors }\end{array}$ \\
\hline \multicolumn{9}{|c|}{ PI3K inhibitors } \\
\hline SF1126 & NCT03059147 & 14 & I & Nivolumab & $\begin{array}{c}\text { SF1126 IV } \\
\text { 900-1100 mg/m² } \\
\text { twice weekly + } \\
\text { nivolumab } 240 \mathrm{mg} \text { IV } \\
\text { every } 2 \text { weeks }\end{array}$ & 2017 & $\begin{array}{l}\text { Active, not } \\
\text { recruiting }\end{array}$ & \\
\hline \multicolumn{9}{|c|}{ Akt inhibitors } \\
\hline Erlotinib & NCT01180959 & 45 & II & Bevacizumab & $\begin{array}{c}\text { Erlotinib } 150 \text { mg PO } \\
\text { OD + bevacizumab IV } \\
10 \text { mg/kg once every } \\
2 \text { weeks }\end{array}$ & 2010 & $\begin{array}{l}\text { Completed, no } \\
\text { results }\end{array}$ & $\begin{array}{l}\text { As second-line } \\
\text { therapy for those } \\
\text { with previous } \\
\text { sorafenib } \\
\text { treatment }\end{array}$ \\
\hline MK2206 & NCT01425879 & 8 & II & & $\begin{array}{l}\text { Dosage not specified, } \\
\text { but PO every } 7 \text { days }\end{array}$ & 2011 & Completed & $\begin{array}{l}\text { Not specifically for } \\
\text { HCC patients- } \\
\text { unknown number } \\
\text { of HCC patients }\end{array}$ \\
\hline MK2206 & NCT01239355 & 15 & II & & $\begin{array}{l}\text { Dosage not specified, } \\
\text { but PO every } 7 \text { days }\end{array}$ & 2010 & Terminated & $\begin{array}{l}\text { Early termination } \\
\text { due to } \\
\text { discouraging } \\
\text { results }\end{array}$ \\
\hline \multicolumn{9}{|c|}{ mTOR inhibitors } \\
\hline RAD001 & NCT00516165 & 28 & $\mathrm{I} / \mathrm{II}$ & RAD001 & $10 \mathrm{mg}$ PO OD & 2007 & Completed & $\begin{array}{c}\mathrm{P} / \mathrm{E} \text { and blood test } \\
\text { each week and } \\
\text { imaging every } \\
\text { 6-12 weeks }\end{array}$ \\
\hline RAD001 & NCT00775073 & 33 & III & Bevacizumab & $\begin{array}{c}\text { Everolimus } 5 \text { mg PO } \\
\text { OD, bevacizumab } \\
5 \mathrm{mg} / \mathrm{kg} \text { IV every } \\
2 \text { weeks }\end{array}$ & 2008 & $\begin{array}{l}\text { Completed, no } \\
\text { results }\end{array}$ & \\
\hline
\end{tabular}


Table 2. Cont.

\begin{tabular}{|c|c|c|c|c|c|c|c|c|}
\hline Drugs & NCT \# & Patients & Phase & Combinations & Dosage & Year & Status & Notes \\
\hline Everolimus & NCT01035229 & 546 & III & Everolimus & $7.5 \mathrm{mg}$ PO OD & 2009 & Completed & \\
\hline Everolimus & NCT01005199 & 106 & III & Sorafenib & $\begin{array}{c}\text { Everolimus } 5 \mathrm{mg} \text { PO } \\
\text { OD, sorafenib } 800 \mathrm{mg} \\
\text { PO OD }\end{array}$ & 2009 & $\begin{array}{l}\text { Completed, no } \\
\text { results }\end{array}$ & \\
\hline Everolimus & NCT04803318 & 100 & III & Trametinib, lenvatinib & $\begin{array}{l}\text { PO, dosage not } \\
\text { specified }\end{array}$ & 2021 & Recruiting & $\begin{array}{l}\text { Not specific for } \\
\text { HCC, for recur- } \\
\text { rent/refractory } \\
\text { advanced solid } \\
\quad \text { tumors }\end{array}$ \\
\hline Sirolimus & NCT00467194 & 27 & I & Bevacizumab & $\begin{array}{l}\text { Sirolimus } 1 \text { mg PO } \\
\text { OD, bevacizumab IV } \\
100 \text { mg every } 2 \text { weeks }\end{array}$ & 2007 & $\begin{array}{l}\text { Completed, no } \\
\text { results }\end{array}$ & \\
\hline Temsirolimus & NCT01008917 & 25 & I & Sorafenib & $\begin{array}{c}\text { Temsirolimus IV } \\
\text { weekly, sorafenib PO } \\
\text { OD }\end{array}$ & 2009 & $\begin{array}{l}\text { Completed, no } \\
\text { results }\end{array}$ & $\begin{array}{l}\text { Combined phase } \\
\text { I/II study }\end{array}$ \\
\hline Temsirolimus & NCT01687673 & 29 & II & Sorafenib & $\begin{array}{l}\text { Temsirolimus IV } 10 \\
\text { mg weekly, sorafenib } \\
200 \text { mg PO BD }\end{array}$ & 2012 & $\begin{array}{l}\text { Completed, results } \\
\text { available }\end{array}$ & \\
\hline Temsirolimus & NCT01010126 & 252 & II & Bevacizumab & $\begin{array}{l}\text { Temsirolimus IV } \\
\text { weekly, bevacizumab } \\
\text { IV every } 2 \text { weeks }\end{array}$ & 2009 & $\begin{array}{l}\text { Completed, results } \\
\text { available }\end{array}$ & $\begin{array}{l}\text { Not specific for } \\
\text { HCC, for } \\
\text { advanced } \\
\text { endometrial, } \\
\text { ovarian, liver, } \\
\text { carcinoid or islet } \\
\text { cell cancer }\end{array}$ \\
\hline $\begin{array}{l}\text { Nab-rapamycin/ } \\
\text { ABI-009 }\end{array}$ & NCT03190174 & 40 & $\mathrm{I} / \mathrm{II}$ & Nivolumab & $\begin{array}{c}\text { Escalating dose of } \\
\text { ABI-009 IV once every } \\
\text { three weeks, } \\
\text { nivolumab } 3 \mathrm{mg} / \mathrm{kg} \\
\text { IV every three weeks }\end{array}$ & 2017 & Recruiting & $\begin{array}{c}\text { Not specific for } \\
\text { HCC, for } \\
\text { advanced sarcoma } \\
\text { and certain } \\
\text { cancers }\end{array}$ \\
\hline
\end{tabular}


Table 2. Cont.

\begin{tabular}{|c|c|c|c|c|c|c|c|c|}
\hline Drugs & NCT \# & Patients & Phase & Combinations & Dosage & Year & Status & Notes \\
\hline CC-223 & NCT01177397 & 173 & $\mathrm{I} / \mathrm{II}$ & & $\begin{array}{l}\text { CC-233 dose starting } \\
\text { at } 7.5 \text { mg PO OD, } \\
\text { dose-escalation }\end{array}$ & 2010 & $\begin{array}{l}\text { Completed, no } \\
\text { results }\end{array}$ & $\begin{array}{l}\text { Not specific for } \\
\text { HCC, for } \\
\text { advanced solid } \\
\text { tumors, } \\
\text { non-Hodgkin } \\
\text { lymphoma or } \\
\text { multiple myeloma }\end{array}$ \\
\hline ATG-008 & NCT04518137 & 48 & II & & $\begin{array}{c}\text { ATG-008 } 30 \mathrm{mg} \text { PO, } \\
\text { OD }\end{array}$ & 2020 & Recruiting & $\begin{array}{l}\text { Not specific for } \\
\text { HCC, for } \\
\text { advanced solid } \\
\text { tumors }\end{array}$ \\
\hline ATG-008 & NCT03591965 & 75 & II & & $\begin{array}{l}\text { ATG-008 } 45 \mathrm{mg} \text { PO } \\
\text { OD, ATG-008 } 20 \mathrm{mg} \\
\text { PO BD }\end{array}$ & 2018 & Recruiting & $\begin{array}{l}\text { Hep B positive } \\
\text { HCC patients with } \\
\text { prior exposure to } \\
\text { systemic therapy }\end{array}$ \\
\hline
\end{tabular}




\section{Conclusions}

Cumulative evidence illustrates the importance of the PI3K/Akt/mTOR signaling pathway in tumorigenesis and HCC progression. The PI3K/Akt/mTOR pathway is overexpressed in nearly $50 \%$ of HCCs and the dysregulated activation of this pathway affects a wide range of processes, including cell proliferation, metabolism, tumor cell differentiation, lipid metabolism, autophagy, and EMT $[123,124]$. Due to these mechanistic connections, the current available first-line drugs are multitargeted tyrosine kinase inhibitors that focus on the PI3K/Akt/mTOR pathway. However, these inhibitors can only modestly extend life; the patients invariably acquire resistance and this in turn leads to limited pharmaceutical options. Thus, with the expected growth in HCC cases worldwide, there is an urgency for the development of safer and more efficient treatment options for advanced HCC patients who are not eligible for surgical resection. In this manner, a key challenge for $\mathrm{PI} 3 \mathrm{~K} / \mathrm{Akt} / \mathrm{mTOR}$ pathway inhibition will be to understand the cross-talk and feedback into other pathways and establish methods to diagnose these significant adaptive signaling changes. This could involve more invasive management before and after treatment to determine the basis of each patient's tumor genetics and signaling changes, the development of patient spheriod screening for drug testing, or the utilization of novel liquid biopsy techniques. Additionally, as is evident from the listed clinical trials, combinations of systemic therapies need to be tested to establish systemic effects and efficacy, develop better inhibitors, and use novel delivery technologies to direct the drug to the tumor. Together, these future developments will reduce side effects and improve life expectancy.

Author Contributions: E.J.S. and L.H. conceived and wrote the article. M.W., P.P. and C.M. provided input and revision comments. All authors have read and agreed to the published version of the manuscript.

Funding: We wish to acknowledge financial support from a Study, education and research trust account research grant from the Townsville Hospital and Health Service (THHS SERTA 09_2020; P.P., L.H., C.M. and M.W.) and a Project Grant from the Gastroenterological Society of Australia (L.H.).

Institutional Review Board Statement: Not applicable.

Informed Consent Statement: Not applicable.

Data Availability Statement: Not applicable.

Conflicts of Interest: The authors declare no conflict of interest.

\section{References}

1. Utibe-Abasi, U.; Sanabria, J.D.; Rajan, P.K.; Banerjee, M.; Schade, M.; Sanabria, J.A.; Smith, G.; Udoh, G.; Sodhi, K.; Pierre, S.; et al. Non-Alcoholic Fatty Liver Disease Progression to Non-Alcoholic Steatohepatitis-Related Primary Liver Cancer; Exon Publications: Brisbane, Australia, 2021. [CrossRef]

2. Wang, H.; Naghavi, M.; Allen, C.; Barber, R.M.; Bhutta, Z.A.; Carter, A.; Casey, D.C.; Charlson, F.J; Chen, A.Z.; Coates, M.M.; et al. Global, regional, and national life expectancy, all-cause mortality, and cause-specific mortality for 249 causes of death, 1980-2015: A systematic analysis for the Global Burden of Disease Study 2015. Lancet 2016, 388, 1459-1544. [CrossRef]

3. Global Burden of Disease Liver Cancer Collaboration. The Burden of Primary Liver Cancer and Underlying Etiologies From 1990 to 2015 at the Global, Regional, and National Level: Results From the Global Burden of Disease Study 2015. JAMA Oncol. 2017, 3 , 1683-1691. [CrossRef]

4. Bray, F.; Ferlay, J.; Soerjomataram, I.; Siegel, R.L.; Torre, L.A.; Jemal, A. Global cancer statistics 2018: GLOBOCAN estimates of incidence and mortality worldwide for 36 cancers in 185 countries. CA Cancer J. Clin. 2018, 68, 394-424. [CrossRef]

5. Sanyal, A.; Poklepovic, A.; Moyneur, E.; Barghout, V. Population-based risk factors and resource utilization for HCC: US perspective. Curr. Med. Res. Opin. 2010, 26, 2183-2191. [CrossRef]

6. Montella, M.; Crispo, A.; Giudice, A. HCC, diet and metabolic factors: Diet and HCC. Hepat. Mon. 2011, 11, 159-162.

7. Eslam, M.; Sanyal, A.J.; George, J.; International Consensus, P. MAFLD: A Consensus-Driven Proposed Nomenclature for Metabolic Associated Fatty Liver Disease. Gastroenterology 2020, 158, 1999-2014.e1. [CrossRef] [PubMed]

8. Yao, Y.J.; Ping, X.L.; Zhang, H.; Chen, F.F.; Lee, P.K.; Ahsan, H.; Chen, C.J.; Lee, P.H.; Peacocke, M.; Santella, R.M.; et al. PTEN/MMAC1 mutations in hepatocellular carcinomas. Oncogene 1999, 18, 3181-3185. [CrossRef] [PubMed] 
9. Sahin, F.; Kannangai, R.; Adegbola, O.; Wang, J.; Su, G.; Torbenson, M. mTOR and P70 S6 kinase expression in primary liver neoplasms. Clin. Cancer Res. 2004, 10, 8421-8425. [CrossRef] [PubMed]

10. Villanueva, A.; Chiang, D.Y.; Newell, P.; Peix, J.; Thung, S.; Alsinet, C.; Tovar, V.; Roayaie, S.; Minguez, B.; Sole, M.; et al. Pivotal role of mTOR signaling in hepatocellular carcinoma. Gastroenterology 2008, 135, 1972-1983.e1. [CrossRef] [PubMed]

11. Liu, L.; Cao, Y.; Chen, C.; Zhang, X.; McNabola, A.; Wilkie, D.; Wilhelm, S.; Lynch, M.; Carter, C. Sorafenib blocks the $\mathrm{RAF} / \mathrm{MEK} / \mathrm{ERK}$ pathway, inhibits tumor angiogenesis, and induces tumor cell apoptosis in hepatocellular carcinoma model PLC/PRF/5. Cancer Res. 2006, 66, 11851-11858. [CrossRef] [PubMed]

12. Sieghart, W.; Fuereder, T.; Schmid, K.; Cejka, D.; Werzowa, J.; Wrba, F.; Wang, X.; Gruber, D.; Rasoul-Rockenschaub, S.; Peck-Radosavljevic, M.; et al. Mammalian target of rapamycin pathway activity in hepatocellular carcinomas of patients undergoing liver transplantation. Transplantation 2007, 83, 425-432. [CrossRef]

13. Llovet, J.M.; Ricci, S.; Mazzaferro, V.; Hilgard, P.; Gane, E.; Blanc, J.-F.; de Oliveira, A.C.; Santoro, A.; Raoul, J.-L.; Forner, A.; et al. Sorafenib in Advanced Hepatocellular Carcinoma. N. Engl. J. Med. 2008, 359, 378-390. [CrossRef]

14. Lin, L.; Yan, L.; Liu, Y.; Qu, C.; Ni, J.; Li, H. The Burden and Trends of Primary Liver Cancer Caused by Specific Etiologies from 1990 to 2017 at the Global, Regional, National, Age, and Sex Level Results from the Global Burden of Disease Study 2017. Liver Cancer 2020, 9, 563-582. [CrossRef] [PubMed]

15. Liu, Z.; Jiang, Y.; Yuan, H.; Fang, Q.; Cai, N.; Suo, C.; Jin, L.; Zhang, T.; Chen, X. The trends in incidence of primary liver cancer caused by specific etiologies: Results from the Global Burden of Disease Study 2016 and implications for liver cancer prevention. J. Hepatol. 2019, 70, 674-683. [CrossRef] [PubMed]

16. Dyson, J.K.; Anstee, Q.M.; McPherson, S. Non-alcoholic fatty liver disease: A practical approach to diagnosis and staging. Frontline Gastroenterol. 2014, 5, 211-218. [CrossRef]

17. Chalasani, N.; Younossi, Z.; Lavine, J.E.; Charlton, M.; Cusi, K.; Rinella, M.; Harrison, S.A.; Brunt, E.M.; Sanyal, A.J. The diagnosis and management of nonalcoholic fatty liver disease: Practice guidance from the American Association for the Study of Liver Diseases. Hepatology 2018, 67, 328-357. [CrossRef] [PubMed]

18. Golabi, P.; Otgonsuren, M.; de Avila, L.; Sayiner, M.; Rafiq, N.; Younossi, Z.M. Components of metabolic syndrome increase the risk of mortality in nonalcoholic fatty liver disease (NAFLD). Medicine (Baltimore) 2018, 97, e214. [CrossRef]

19. Estes, C.; Razavi, H.; Loomba, R.; Younossi, Z.; Sanyal, A.J. Modeling the epidemic of nonalcoholic fatty liver disease demonstrates an exponential increase in burden of disease. Hepatology 2018, 67, 123-133. [CrossRef]

20. Anwanwan, D.; Singh, S.K.; Singh, S.; Saikam, V.; Singh, R. Challenges in liver cancer and possible treatment approaches. Biochim. Biophys. Acta (BBA)—Rev. Cancer 2020, 1873, 188314. [CrossRef]

21. Kudo, M.; Ueshima, K.; Ikeda, M.; Torimura, T.; Tanabe, N.; Aikata, H.; Izumi, N.; Yamasaki, T.; Nojiri, S.; Hino, K.; et al. Randomised, multicentre prospective trial of transarterial chemoembolisation (TACE) plus sorafenib as compared with TACE alone in patients with hepatocellular carcinoma: TACTICS trial. Gut 2020, 69, 1492. [CrossRef]

22. Faivre, S.; Rimassa, L.; Finn, R.S. Molecular therapies for HCC: Looking outside the box. J. Hepatol. 2020, 72, 342-352. [CrossRef] [PubMed]

23. Wilhelm, S.M.; Adnane, L.; Newell, P.; Villanueva, A.; Llovet, J.M.; Lynch, M. Preclinical overview of sorafenib, a multikinase inhibitor that targets both Raf and VEGF and PDGF receptor tyrosine kinase signaling. Mol. Cancer Ther. 2008, 7, 3129. [CrossRef] [PubMed]

24. Fondevila, F.; Méndez-Blanco, C.; Fernández-Palanca, P.; González-Gallego, J.; Mauriz, J.L. Anti-tumoral activity of single and combined regorafenib treatments in preclinical models of liver and gastrointestinal cancers. Exp. Mol. Med. 2019, 51, 1-15. [CrossRef]

25. El-Serag, H.B.; Marrero, J.A.; Rudolph, L.; Reddy, K.R. Diagnosis and Treatment of Hepatocellular Carcinoma. Gastroenterology 2008, 134, 1752-1763. [CrossRef]

26. Manning, B.D.; Cantley, L.C. AKT/PKB signaling: Navigating downstream. Cell 2007, 129, 1261-1274. [CrossRef] [PubMed]

27. Sever, R.; Brugge, J.S. Signal transduction in cancer. Cold Spring Harb. Perspect. Med. 2015, 5, a006098. [CrossRef] [PubMed]

28. Khan, K.H.; Yap, T.A.; Yan, L.; Cunningham, D. Targeting the PI3K-AKT-mTOR signaling network in cancer. Chin. J. Cancer 2013, 32, 253-265. [CrossRef]

29. Lemmon, M.A.; Schlessinger, J. Cell signaling by receptor tyrosine kinases. Cell 2010, 141, 1117-1134. [CrossRef]

30. Franke, T.F. PI3K/Akt: Getting it right matters. Oncogene 2008, 27, 6473-6488. [CrossRef]

31. Czech, M.P. PIP2 and PIP3: Complex Roles at the Cell Surface. Cell 2000, 100, 603-606. [CrossRef]

32. Maehama, T.; Dixon, J.E. The Tumor Suppressor, PTEN/MMAC1, Dephosphorylates the Lipid Second Messenger, Phosphatidylinositol 3,4,5-Trisphosphate*. J. Biol. Chem. 1998, 273, 13375-13378. [CrossRef] [PubMed]

33. Dieterle, A.M.; Böhler, P.; Keppeler, H.; Alers, S.; Berleth, N.; Drießen, S.; Hieke, N.; Pietkiewicz, S.; Löffler, A.S.; Peter, C.; et al. PDK1 controls upstream PI3K expression and PIP3 generation. Oncogene 2014, 33, 3043-3053. [CrossRef]

34. Manning, B.D.; Toker, A. AKT/PKB Signaling: Navigating the Network. Cell 2017, 169, 381-405. [CrossRef] [PubMed]

35. Gao, Y.; Moten, A.; Lin, H.-K. Akt: A new activation mechanism. Cell Res. 2014, 24, 785-786. [CrossRef] [PubMed]

36. Kim, L.C.; Cook, R.S.; Chen, J. mTORC1 and mTORC2 in cancer and the tumor microenvironment. Oncogene 2017, 36, $2191-2201$. [CrossRef]

37. Singh, S.S.; Vats, S.; Chia, A.Y.; Tan, T.Z.; Deng, S.; Ong, M.S.; Arfuso, F.; Yap, C.T.; Goh, B.C.; Sethi, G.; et al. Dual role of autophagy in hallmarks of cancer. Oncogene 2018, 37, 1142-1158. [CrossRef] 
38. Paquette, M.; El-Houjeiri, L.; Pause, A. mTOR Pathways in Cancer and Autophagy. Cancers 2018, 10, 18. [CrossRef]

39. Evangelisti, C.; Chiarini, F.; Paganelli, F.; Marmiroli, S.; Martelli, A.M. Crosstalks of GSK3 signaling with the mTOR network and effects on targeted therapy of cancer. Biochim. Biophys. Acta (BBA)-Mol. Cell Res. 2020, 1867, 118635. [CrossRef]

40. Mancinelli, R.; Carpino, G.; Petrungaro, S.; Mammola, C.L.; Tomaipitinca, L.; Filippini, A.; Facchiano, A.; Ziparo, E.; Giampietri, C. Multifaceted Roles of GSK-3 in Cancer and Autophagy-Related Diseases. Oxid. Med. Cell. Longev. 2017, 2017, 4629495. [CrossRef]

41. Beurel, E.; Grieco, S.F.; Jope, R.S. Glycogen synthase kinase-3 (GSK3): Regulation, actions, and diseases. Pharmacol. Ther. 2015, 148, 114-131. [CrossRef]

42. Wang, H.; Liu, Y.; Wang, D.; Xu, Y.; Dong, R.; Yang, Y.; Lv, Q.; Chen, X.; Zhang, Z. The Upstream Pathway of mTOR-Mediated Autophagy in Liver Diseases. Cells 2019, 8, 1597. [CrossRef] [PubMed]

43. He, L.; Gomes, A.P.; Wang, X.; Yoon, S.O.; Lee, G.; Nagiec, M.J.; Cho, S.; Chavez, A.; Islam, T.; Yu, Y.; et al. mTORC1 Promotes Metabolic Reprogramming by the Suppression of GSK3-Dependent Foxk1 Phosphorylation. Mol. Cell 2018, 70, 949-960.e4. [CrossRef] [PubMed]

44. Fang, G.; Zhang, P.; Liu, J.; Zhang, X.; Zhu, X.; Li, R.; Wang, H. Inhibition of GSK-3beta activity suppresses HCC malignant phenotype by inhibiting glycolysis via activating AMPK/mTOR signaling. Cancer Lett. 2019, 463, 11-26. [CrossRef] [PubMed]

45. Sapio, L.; Salzillo, A.; Ragone, A.; Illiano, M.; Spina, A.; Naviglio, S. Targeting CREB in Cancer Therapy: A Key Candidate or One of Many? An Update. Cancers 2020, 12, 3166. [CrossRef]

46. Steven, A.; Friedrich, M.; Jank, P.; Heimer, N.; Budczies, J.; Denkert, C.; Seliger, B. What turns CREB on? And off? And why does it matter? Cell. Mol. Life Sci. 2020, 77, 4049-4067. [CrossRef]

47. Yu, L.; Guo, X.; Zhang, P.; Qi, R.; Li, Z.; Zhang, S. Cyclic adenosine monophosphate-responsive element-binding protein activation predicts an unfavorable prognosis in patients with hepatocellular carcinoma. Onco Targets Ther. 2014, 7, 873-879. [CrossRef]

48. Kovach, S.J.; Price, J.A.; Shaw, C.M.; Theodorakis, N.G.; McKillop, I.H. Role of cyclic-AMP responsive element binding (CREB) proteins in cell proliferation in a rat model of hepatocellular carcinoma. J. Cell. Physiol. 2006, 206, 411-419. [CrossRef]

49. Shneor, D.; Folberg, R.; Pe'er, J.; Honigman, A.; Frenkel, S. Stable knockdown of CREB, HIF-1 and HIF-2 by replication-competent retroviruses abrogates the responses to hypoxia in hepatocellular carcinoma. Cancer Gene Ther. 2017, 24, 64-74. [CrossRef]

50. Abramovitch, R.; Tavor, E.; Jacob-Hirsch, J.; Zeira, E.; Amariglio, N.; Pappo, O.; Rechavi, G.; Galun, E.; Honigman, A. A pivotal role of cyclic AMP-responsive element binding protein in tumor progression. Cancer Res. 2004, 64, 1338-1346. [CrossRef]

51. Wang, J.; Ma, L.; Weng, W.; Qiao, Y.; Zhang, Y.; He, J.; Wang, H.; Xiao, W.; Li, L.; Chu, Q.; et al. Mutual interaction between YAP and CREB promotes tumorigenesis in liver cancer. Hepatology 2013, 58, 1011-1020. [CrossRef]

52. Zhang, T.; Zhang, J.; You, X.; Liu, Q.; Du, Y.; Gao, Y.; Shan, C.; Kong, G.; Wang, Y.; Yang, X.; et al. Hepatitis B virus X protein modulates oncogene Yes-associated protein by CREB to promote growth of hepatoma cells. Hepatology 2012, 56, 2051-2059. [CrossRef] [PubMed]

53. Park, S.I.; Park, S.-J.; Lee, J.; Kim, H.E.; Park, S.J.; Sohn, J.-W.; Park, Y.G. Inhibition of cyclic AMP response element-directed transcription by decoy oligonucleotides enhances tumor-specific radiosensitivity. Biochem. Biophys. Res. Commun. 2016, 469, 363-369. [CrossRef] [PubMed]

54. Carbajo-Pescador, S.; Mauriz, J.L.; García-Palomo, A.; González-Gallego, J. FoxO proteins: Regulation and molecular targets in liver cancer. Curr. Med. Chem. 2014, 21, 1231-1246. [CrossRef] [PubMed]

55. Yang, S.; Pang, L.; Dai, W.; Wu, S.; Ren, T.; Duan, Y.; Zheng, Y.; Bi, S.; Zhang, X.; Kong, J. Role of Forkhead Box O Proteins in Hepatocellular Carcinoma Biology and Progression (Review). Front. Oncol. 2021, 11, 1797. [CrossRef]

56. Hay, N. Interplay between FOXO, TOR, and Akt. Biochim. Biophys. Acta 2011, 1813, 1965-1970. [CrossRef]

57. Dong, T.; Zhang, Y.; Chen, Y.; Liu, P.; An, T.; Zhang, J.; Yang, H.; Zhu, W.; Yang, X. FOXO1 inhibits the invasion and metastasis of hepatocellular carcinoma by reversing ZEB2-induced epithelial-mesenchymal transition. Oncotarget 2017, 8, 1703-1713. [CrossRef] [PubMed]

58. Song, S.-S.; Ying, J.-F.; Zhang, Y.-N.; Pan, H.-Y.; He, X.-L.; Hu, Z.-M.; Wang, H.-J.; Dou, X.-B.; Mou, X.-Z. High expression of FOXO3 is associated with poor prognosis in patients with hepatocellular carcinoma. Oncol. Lett. 2020, 19, 3181-3188. [CrossRef]

59. Ahn, H.; Kim, H.; Abdul, R.; Kim, Y.; Sim, J.; Choi, D.; Paik, S.S.; Shin, S.-J.; Kim, D.-H.; Jang, K. Overexpression of Forkhead Box O3a and Its Association With Aggressive Phenotypes and Poor Prognosis in Human Hepatocellular Carcinoma. Am. J. Clin. Pathol. 2018, 149, 117-127. [CrossRef]

60. Lu, M.; Hartmann, D.; Braren, R.; Gupta, A.; Wang, B.; Wang, Y.; Mogler, C.; Cheng, Z.; Wirth, T.; Friess, H.; et al. Oncogenic Akt-FOXO3 loop favors tumor-promoting modes and enhances oxidative damage-associated hepatocellular carcinogenesis. BMC Cancer 2019, 19, 887. [CrossRef]

61. Liang, C.; Dong, Z.; Cai, X.; Shen, J.; Xu, Y.; Zhang, M.; Li, H.; Yu, W.; Chen, W. Hypoxia induces sorafenib resistance mediated by autophagy via activating FOXO3a in hepatocellular carcinoma. Cell Death Dis. 2020, 11, 1017. [CrossRef]

62. Vousden, K.H. p53: Death Star. Cell 2000, 103, 691-694. [CrossRef]

63. Kancherla, V.; Abdullazade, S.; Matter, M.S.; Lanzafame, M.; Quagliata, L.; Roma, G.; Hoshida, Y.; Terracciano, L.M.; Ng, C.K.Y.; Piscuoglio, S. Genomic Analysis Revealed New Oncogenic Signatures in TP53-Mutant Hepatocellular Carcinoma. Front. Genet. 2018, 9, 2. [CrossRef] [PubMed]

64. Kew, M.C. Epidemiology of chronic hepatitis B virus infection, hepatocellular carcinoma, and hepatitis B virus-induced hepatocellular carcinoma. Pathol. Biol. 2010, 58, 273-277. [CrossRef] [PubMed] 
65. Ogawara, Y.; Kishishita, S.; Obata, T.; Isazawa, Y.; Suzuki, T.; Tanaka, K.; Masuyama, N.; Gotoh, Y. Akt enhances Mdm2-mediated ubiquitination and degradation of p53. J. Biol. Chem. 2002, 277, 21843-21850. [CrossRef] [PubMed]

66. Mayo, L.D.; Donner, D.B. A phosphatidylinositol 3-kinase/Akt pathway promotes translocation of Mdm2 from the cytoplasm to the nucleus. Proc. Natl. Acad. Sci. USA 2001, 98, 11598-11603. [CrossRef] [PubMed]

67. Zhou, B.P.; Liao, Y.; Xia, W.; Zou, Y.; Spohn, B.; Hung, M.C. HER-2/neu induces p53 ubiquitination via Akt-mediated MDM2 phosphorylation. Nat. Cell Biol. 2001, 3, 973-982. [CrossRef] [PubMed]

68. Chibaya, L.; Karim, B.; Zhang, H.; Jones, S.N. Mdm2 phosphorylation by Akt regulates the p53 response to oxidative stress to promote cell proliferation and tumorigenesis. Proc. Natl. Acad. Sci. USA 2021, 118, e2003193118. [CrossRef] [PubMed]

69. Stambolic, V.; MacPherson, D.; Sas, D.; Lin, Y.; Snow, B.; Jang, Y.; Benchimol, S.; Mak, T.W. Regulation of PTEN transcription by p53. Mol. Cell 2001, 8, 317-325. [CrossRef]

70. Feng, Z.; Hu, W.; de Stanchina, E.; Teresky, A.K.; Jin, S.; Lowe, S.; Levine, A.J. The regulation of AMPK beta1, TSC2, and PTEN expression by p53: Stress, cell and tissue specificity, and the role of these gene products in modulating the IGF-1-AKT-mTOR pathways. Cancer Res. Res. 2007, 67, 3043-3053. [CrossRef]

71. Budanov, A.V.; Karin, M. p53 target genes sestrin1 and sestrin2 connect genotoxic stress and mTOR signaling. Cell 2008, 134, 451-460. [CrossRef]

72. Brugarolas, J.; Lei, K.; Hurley, R.L.; Manning, B.D.; Reiling, J.H.; Hafen, E.; Witters, L.A.; Ellisen, L.W.; Kaelin, W.G., Jr. Regulation of mTOR function in response to hypoxia by REDD1 and the TSC1/TSC2 tumor suppressor complex. Genes Dev. 2004, 18, 2893-2904. [CrossRef]

73. DeYoung, M.P.; Horak, P.; Sofer, A.; Sgroi, D.; Ellisen, L.W. Hypoxia regulates TSC1/2-mTOR signaling and tumor suppression through REDD1-mediated 14-3-3 shuttling. Genes Dev. 2008, 22, 239-251. [CrossRef] [PubMed]

74. Maddocks, O.D.K.; Vousden, K.H. Metabolic regulation by p53. J. Mol. Med. 2011, 89, 237-245. [CrossRef] [PubMed]

75. Luo, Y.-D.; Fang, L.; Yu, H.-Q.; Zhang, J.; Lin, X.-T.; Liu, X.-Y.; Wu, D.; Li, G.-X.; Huang, D.; Zhang, Y.-J.; et al. p53 haploinsufficiency and increased mTOR signalling define a subset of aggressive hepatocellular carcinoma. J. Hepatol. 2021, 74, 96-108. [CrossRef]

76. Luedde, T.; Schwabe, R.F. NF-кB in the liver-linking injury, fibrosis and hepatocellular carcinoma. Nat. Rev. Gastroenterol. Hepatol. 2011, 8, 108-118. [CrossRef] [PubMed]

77. Perkins, N.D. The diverse and complex roles of NF-kB subunits in cancer. Nat. Rev. Cancer 2012, 12, 121-132. [CrossRef]

78. Taniguchi, K.; Karin, M. NF-кB, inflammation, immunity and cancer: Coming of age. Nat. Rev. Immunol. 2018, 18, 309-324. [CrossRef]

79. Ozes, O.N.; Mayo, L.D.; Gustin, J.A.; Pfeffer, S.R.; Pfeffer, L.M.; Donner, D.B. NF-kappaB activation by tumour necrosis factor requires the Akt serine-threonine kinase. Nature 1999, 401, 82-85. [CrossRef]

80. Dan, H.C.; Cooper, M.J.; Cogswell, P.C.; Duncan, J.A.; Ting, J.P.; Baldwin, A.S. Akt-dependent regulation of NF-\{kappa\}B is controlled by mTOR and Raptor in association with IKK. Genes Dev. 2008, 22, 1490-1500. [CrossRef]

81. Kane, L.P.; Mollenauer, M.N.; Xu, Z.; Turck, C.W.; Weiss, A. Akt-dependent phosphorylation specifically regulates Cot induction of NF-kappa B-dependent transcription. Mol. Cell Biol. 2002, 22, 5962-5974. [CrossRef]

82. Wu, J.-M.; Sheng, H.; Saxena, R.; Skill, N.J.; Bhat-Nakshatri, P.; Yu, M.; Nakshatri, H.; Maluccio, M.A. NF-kB inhibition in human hepatocellular carcinoma and its potential as adjunct to sorafenib based therapy. Cancer Lett. 2009, 278, 145-155. [CrossRef] [PubMed]

83. Maeda, S.; Kamata, H.; Luo, J.-L.; Leffert, H.; Karin, M. IKK $\beta$ Couples Hepatocyte Death to Cytokine-Driven Compensatory Proliferation that Promotes Chemical Hepatocarcinogenesis. Cell 2005, 121, 977-990. [CrossRef]

84. Horton, J.D.; Goldstein, J.L.; Brown, M.S. SREBPs: Activators of the complete program of cholesterol and fatty acid synthesis in the liver. J. Clin. Investig. 2002, 109, 1125-1131. [CrossRef] [PubMed]

85. Laplante, M.; Sabatini, D.M. An emerging role of mTOR in lipid biosynthesis. Curr. Biol. 2009, 19, R1046-R1052. [CrossRef] [PubMed]

86. Koundouros, N.; Poulogiannis, G. Reprogramming of fatty acid metabolism in cancer. Br. J. Cancer 2020, 122, 4-22. [CrossRef] [PubMed]

87. Li, C.; Yang, W.; Zhang, J.; Zheng, X.; Yao, Y.; Tu, K.; Liu, Q. SREBP-1 has a prognostic role and contributes to invasion and metastasis in human hepatocellular carcinoma. Int. J. Mol. Sci. 2014, 15, 7124-7138. [CrossRef] [PubMed]

88. Li, N.; Zhou, Z.-S.; Shen, Y.; Xu, J.; Miao, H.-H.; Xiong, Y.; Xu, F.; Li, B.-L.; Luo, J.; Song, B.-L. Inhibition of the sterol regulatory element-binding protein pathway suppresses hepatocellular carcinoma by repressing inflammation in mice. Hepatology 2017, 65, 1936-1947. [CrossRef] [PubMed]

89. Peterson, T.R.; Sengupta, S.S.; Harris, T.E.; Carmack, A.E.; Kang, S.A.; Balderas, E.; Guertin, D.A.; Madden, K.L.; Carpenter, A.E.; Finck, B.N.; et al. mTOR complex 1 regulates lipin 1 localization to control the SREBP pathway. Cell 2011, 146, 408-420. [CrossRef]

90. Lee, G.; Zheng, Y.; Cho, S.; Jang, C.; England, C.; Dempsey, J.M.; Yu, Y.; Liu, X.; He, L.; Cavaliere, P.M.; et al. Post-transcriptional Regulation of De Novo Lipogenesis by mTORC1-S6K1-SRPK2 Signaling. Cell 2017, 171, 1545-1558.e1. [CrossRef]

91. Kim, K.H.; Song, M.J.; Yoo, E.J.; Choe, S.S.; Park, S.D.; Kim, J.B. Regulatory role of glycogen synthase kinase 3 for transcriptional activity of ADD1/SREBP1c. J. Biol. Chem. 2004, 279, 51999-52006. [CrossRef]

92. Yecies, J.L.; Zhang, H.H.; Menon, S.; Liu, S.; Yecies, D.; Lipovsky, A.I.; Gorgun, C.; Kwiatkowski, D.J.; Hotamisligil, G.S.; Lee, C.H.; et al. Akt stimulates hepatic SREBP1c and lipogenesis through parallel mTORC1-dependent and independent pathways. Cell Metab. 2011, 14, 21-32. [CrossRef] 
93. Guri, Y.; Colombi, M.; Dazert, E.; Hindupur, S.K.; Roszik, J.; Moes, S.; Jenoe, P.; Heim, M.H.; Riezman, I.; Riezman, H.; et al. mTORC2 Promotes Tumorigenesis via Lipid Synthesis. Cancer Cell 2017, 32, 807-823.e8. [CrossRef]

94. Komatsu, M.; Waguri, S.; Chiba, T.; Murata, S.; Iwata, J.; Tanida, I.; Ueno, T.; Koike, M.; Uchiyama, Y.; Kominami, E.; et al. Loss of autophagy in the central nervous system causes neurodegeneration in mice. Nature 2006, 441, 880-884. [CrossRef] [PubMed]

95. Hansen, M.; Rubinsztein, D.C.; Walker, D.W. Autophagy as a promoter of longevity: Insights from model organisms. Nat. Rev. Mol. Cell Biol. 2018, 19, 579-593. [CrossRef]

96. Kim, J.; Kundu, M.; Viollet, B.; Guan, K.L. AMPK and mTOR regulate autophagy through direct phosphorylation of Ulk1. Nat. Cell Biol. 2011, 13, 132-141. [CrossRef]

97. Alers, S.; Loffler, A.S.; Wesselborg, S.; Stork, B. Role of AMPK-mTOR-Ulk1/2 in the regulation of autophagy: Cross talk, shortcuts, and feedbacks. Mol. Cell Biol. 2012, 32, 2-11. [CrossRef]

98. Russell, R.C.; Yuan, H.-X.; Guan, K.-L. Autophagy regulation by nutrient signaling. Cell Res. 2014, 24, 42-57. [CrossRef]

99. Nie, T.; Yang, S.; Ma, H.; Zhang, L.; Lu, F.; Tao, K.; Wang, R.; Yang, R.; Huang, L.; Mao, Z.; et al. Regulation of ER stress-induced autophagy by GSK3 $\beta$-TIP60-ULK1 pathway. Cell Death Dis. 2016, 7, e2563. [CrossRef] [PubMed]

100. Ryu, H.Y.; Kim, L.E.; Jeong, H.; Yeo, B.K.; Lee, J.W.; Nam, H.; Ha, S.; An, H.K.; Park, H.; Jung, S.; et al. GSK3B induces autophagy by phosphorylating ULK1. Exp. Mol. Med. Med. 2021, 53, 369-383. [CrossRef] [PubMed]

101. Xu, H.; Yu, H.; Zhang, X.; Shen, X.; Zhang, K.; Sheng, H.; Dai, S.; Gao, H. UNC51-like kinase 1 as a potential prognostic biomarker for hepatocellular carcinoma. Int. J. Clin. Exp. Pathol. 2013, 6, 711-717.

102. Xue, S.-T.; Li, K.; Gao, Y.; Zhao, L.-Y.; Gao, Y.; Yi, H.; Jiang, J.-D.; Li, Z.-R. The role of the key autophagy kinase ULK1 in hepatocellular carcinoma and its validation as a treatment target. Autophagy 2020, 16, 1823-1837. [CrossRef] [PubMed]

103. Mendoza, M.C.; Er, E.E.; Blenis, J. The Ras-ERK and PI3K-mTOR pathways: Cross-talk and compensation. Trends Biochem. Sci. 2011, 36, 320-328. [CrossRef] [PubMed]

104. Gedaly, R.; Angulo, P.; Chen, C.; Creasy, K.T.; Spear, B.T.; Hundley, J.; Daily, M.F.; Shah, M.; Evers, B.M. The role of PI3K/mTOR inhibition in combination with sorafenib in hepatocellular carcinoma treatment. Anticancer Res. 2012, 32, $2531-2536$.

105. Moon, H.; Ro, S.W. MAPK/ERK Signaling Pathway in Hepatocellular Carcinoma. Cancers 2021, 13, 3026. [CrossRef] [PubMed]

106. Yang, S.; Liu, G. Targeting the Ras/Raf/MEK/ERK pathway in hepatocellular carcinoma. Oncol. Lett. 2017, 13, 1041-1047. [CrossRef]

107. Cheng, A.L.; Kang, Y.K.; Chen, Z.; Tsao, C.J.; Qin, S.; Kim, J.S.; Luo, R.; Feng, J.; Ye, S.; Yang, T.S.; et al. Efficacy and safety of sorafenib in patients in the Asia-Pacific region with advanced hepatocellular carcinoma: A phase III randomised, double-blind, placebo-controlled trial. Lancet Oncol. 2009, 10, 25-34. [CrossRef]

108. Kudo, M.; Finn, R.S.; Qin, S.; Han, K.H.; Ikeda, K.; Piscaglia, F.; Baron, A.; Park, J.W.; Han, G.; Jassem, J.; et al. Lenvatinib versus sorafenib in first-line treatment of patients with unresectable hepatocellular carcinoma: A randomised phase 3 non-inferiority trial. Lancet 2018, 391, 1163-1173. [CrossRef]

109. Bruix, J.; Qin, S.; Merle, P.; Granito, A.; Huang, Y.H.; Bodoky, G.; Pracht, M.; Yokosuka, O.; Rosmorduc, O.; Breder, V.; et al. Regorafenib for patients with hepatocellular carcinoma who progressed on sorafenib treatment (RESORCE): A randomised, double-blind, placebo-controlled, phase 3 trial. Lancet 2017, 389, 56-66. [CrossRef]

110. Finn, R.S.; Merle, P.; Granito, A.; Huang, Y.H.; Bodoky, G.; Pracht, M.; Yokosuka, O.; Rosmorduc, O.; Gerolami, R.; Caparello, C.; et al. Outcomes of sequential treatment with sorafenib followed by regorafenib for HCC: Additional analyses from the phase III RESORCE trial. J. Hepatol. 2018, 69, 353-358. [CrossRef]

111. Abou-Alfa, G.K.; Meyer, T.; Cheng, A.L.; El-Khoueiry, A.B.; Rimassa, L.; Ryoo, B.Y.; Cicin, I.; Merle, P.; Chen, Y.; Park, J.W.; et al. Cabozantinib in Patients with Advanced and Progressing Hepatocellular Carcinoma. N. Engl. J. Med. 2018, 379, 54-63. [CrossRef] [PubMed]

112. Casak, S.J.; Donoghue, M.; Fashoyin-Aje, L.; Jiang, X.; Rodriguez, L.; Shen, Y.L.; Xu, Y.; Jiang, X.; Liu, J.; Zhao, H.; et al. FDA Approval Summary: Atezolizumab Plus Bevacizumab for the Treatment of Patients with Advanced Unresectable or Metastatic Hepatocellular Carcinoma. Clin. Cancer Res. 2021, 27, 1836-1841. [CrossRef]

113. Finn, R.S.; Qin, S.; Ikeda, M.; Galle, P.R.; Ducreux, M.; Kim, T.Y.; Kudo, M.; Breder, V.; Merle, P.; Kaseb, A.O.; et al. Atezolizumab plus Bevacizumab in Unresectable Hepatocellular Carcinoma. N. Engl. J. Med. 2020, 382, 1894-1905. [CrossRef] [PubMed]

114. Ding, N.; Hah, N.; Yu, R.T.; Sherman, M.H.; Benner, C.; Leblanc, M.; He, M.; Liddle, C.; Downes, M.; Evans, R.M. BRD4 is a novel therapeutic target for liver fibrosis. Proc. Natl. Acad. Sci. USA 2015, 112, 15713-15718. [CrossRef] [PubMed]

115. El-Khoueiry, A.B.; Sangro, B.; Yau, T.; Crocenzi, T.S.; Kudo, M.; Hsu, C.; Kim, T.Y.; Choo, S.P.; Trojan, J.; Welling, T.H.R.; et al. Nivolumab in patients with advanced hepatocellular carcinoma (CheckMate 040): An open-label, non-comparative, phase $1 / 2$ dose escalation and expansion trial. Lancet 2017, 389, 2492-2502. [CrossRef]

116. Yau, T.; Park, J.W.; Finn, R.S.; Cheng, A.L.; Mathurin, P.; Edeline, J.; Kudo, M.; Han, K.H.; Harding, J.J.; Merle, P.; et al. CheckMate 459: A randomized, multi-center phase III study of nivolumab (NIVO) vs sorafenib (SOR) as first-line (1L) treatment in patients (pts) with advanced hepatocellular carcinoma (aHCC). Ann. Oncol. 2019, 30, v874-v875. [CrossRef]

117. Thomas, M.B.; Garrett-Mayer, E.; Anis, M.; Anderton, K.; Bentz, T.; Edwards, A.; Brisendine, A.; Weiss, G.; Siegel, A.B.; Bendell, J.; et al. A Randomized Phase II Open-Label Multi-Institution Study of the Combination of Bevacizumab and Erlotinib Compared to Sorafenib in the First-Line Treatment of Patients with Advanced Hepatocellular Carcinoma. Oncology 2018, 94, 329-339. [CrossRef] 
118. Wang, Z.; Zhou, J.; Fan, J.; Qiu, S.-J.; Yu, Y.; Huang, X.-W.; Tang, Z.-Y. Effect of Rapamycin Alone and in Combination with Sorafenib in an Orthotopic Model of Human Hepatocellular Carcinoma. Clin. Cancer Res. 2008, 14, 5124-5130. [CrossRef] [PubMed]

119. Zhu, A.X.; Kudo, M.; Assenat, E.; Cattan, S.; Kang, Y.K.; Lim, H.Y.; Poon, R.T.; Blanc, J.F.; Vogel, A.; Chen, C.L.; et al. Effect of everolimus on survival in advanced hepatocellular carcinoma after failure of sorafenib: The EVOLVE-1 randomized clinical trial. JAMA 2014, 312, 57-67. [CrossRef]

120. Koeberle, D.; Dufour, J.F.; Demeter, G.; Li, Q.; Ribi, K.; Samaras, P.; Saletti, P.; Roth, A.D.; Horber, D.; Buehlmann, M.; et al. Sorafenib with or without everolimus in patients with advanced hepatocellular carcinoma (HCC): A randomized multicenter, multinational phase II trial (SAKK 77/08 and SASL 29). Ann. Oncol. 2016, 27, 856-861. [CrossRef]

121. Choo, S.P.; Chowbay, B.; Ng, Q.S.; Thng, C.H.; Lim, C.; Hartono, S.; Koh, T.S.; Huynh, H.; Poon, D.; Ang, M.K.; et al. A Phase 1 dose-finding and pharmacodynamic study of rapamycin in combination with bevacizumab in patients with unresectable hepatocellular carcinoma. Eur. J. Cancer 2013, 49, 999-1008. [CrossRef]

122. Knox, J.J.; Qin, R.; Strosberg, J.R.; Tan, B.; Kaubisch, A.; El-Khoueiry, A.B.; Bekaii-Saab, T.S.; Rousey, S.R.; Chen, H.X.; Erlichman, C. A phase II trial of bevacizumab plus temsirolimus in patients with advanced hepatocellular carcinoma. Investig. New Drugs 2015, 33, 241-246. [CrossRef] [PubMed]

123. Porta, C.; Paglino, C.; Mosca, A. Targeting PI3K/Akt/mTOR Signaling in Cancer. Front. Oncol. 2014, 4, 64. [CrossRef] [PubMed]

124. Matter, M.S.; Decaens, T.; Andersen, J.B.; Thorgeirsson, S.S. Targeting the mTOR pathway in hepatocellular carcinoma: Current state and future trends. J. Hepatol. 2014, 60, 855-865. [CrossRef] [PubMed] 